\title{
The Life-history and Cytology of Polyphagus Euglenae.
}

\author{
BY
}

\author{
HAROLD WAGER, F.R.S.
}

With Plates XVI-XIX.

INTRODUCTION.

UR knowledge of this very interesting member of the Chytridiaceae is due to the investigations of Gros ('51), Siebold and Meissner ('55), Bail ('55), A. Braun ('55, '56), A. Schenk ('57), and especially Nowakowski ('76), who has given the most complete account of its general structure and life-history as observed in living specimens.

Nowakowski mentions ('76) that it was first of all described by A. Braun and Bail as Chytridium Euglenae. Subsequently Schenk, regarding the organism as two-celled, separated it from Chytridium and placed it in Rhizidium, but Nowakowski found that it differed in so many particulars from the genera Chytridium and Rhizidium that he felt himself justified in placing it in a new genus under the name Polyphagus.

The cytology of Polyphagus has received little attention. In 1898 I gave a brief account of the structure of the nuclei and of their behaviour during the formation of the zygote, and made further references to it in papers subsequently published ('99 and '05). Dangeard ('00) in a longer memoir confirmed in general my results, and gave some additional details concerning the structure of the zygote and of the asexual sporangium and spores. During the last few years the cytology of various other members of the group has received attention, and the results obtained indicate that a careful study of the Chytridiaceae may give some clue to many interesting problems connected with sexuality and the function of the nuclei in fertilization, and may also throw some light upon the phylogeny of the Fungi.

According to Schroeter ('92, '93), the Chytridiaceae are divided into two very distinctly marked groups. In one, the resting spores are produced asexually, seldom by copulation of swarm spores; in the other, the resting spores are produced by the union of two vegetative cells.

[Annals of Botany, Vol. XXVII. No. CVI. April, 1913.] 
The majority of the genera and species of the Chytridiaceae belong to the first group. In the second group there are only four genera, three of them, Diplophysa, Polyphagus, and Urophlyctis being placed in the subfamily Oochytriae, and a single genus, Zygochytrium, in the sub-family Zygochytriae.

The three genera of the Oochytriae resemble in their vegetative characteristics certain members of the first group, and are in fact only distinguished from them by their sexual reproduction. There seems to be no good reason, therefore, why the Oochytriae should be maintained as a separate sub-family, as the genera included in it might very properly be included in the other sub-families. Thus Diplophysa (Olpidiopsis) would be placed in the Olpidiae, and Urophlyctis in the Cladochytriae. Polyphagus may perhaps be regarded as intermediate between Chytridium and Rhizidium, the two genera of the Rhizidiae. Zygorhizidium Willei, described by Loewenthal, would be included in the Rhizideae. This rearrangement of the genera would simplify the classification of the Chytridiaceae, and the following key, showing how the various sub-families would then be differentiated, may be useful.

\section{Key to the Sub-Families of the Chytridiaceae.}

I. Resting spores produced asexually, rarely by the copulation of swarm spores

I. Sexual spores formed by conjugation, as in Mucorineae

2. Mycelium absent .

2. Mycelium present .

3. Sporangia always single and formed out of the whole mass of the thallus

3. Sporangia in groups or sori .

4. Mycelium in the form of delicate transient strands

4. Mycelium hypha-like, permanent .

5. Mycelium giving rise to one terminal sporangium only, never intercalary

5. Mycelium spreading, often through several cells; sporangia terminal and intercalary . . .

Zygochytriae.

. 3

- Olpidiae. Synchytriae.

Hypochytriae.

- Rhizidiae.

Cladochytriae.

\section{OCCURRENCE AND HABIT.}

Polyphagus Euglenae appeared in abundance in the spring of 1898 on cultures of Euglenae obtained from the Sewage Farm at Keighley in Yorkshire. The Euglenae from which the cultures were made formed a bright green scum on the surface of the drying-up mud or sediment left on the filter beds. The cells were found to be in a resting and slightly 
encysted condition, but on placing them in a saucer of tap-water they soon became motile, and remained in this condition for several days. They then passed into a resting stage again, becoming rounded off and surrounded by a thin membrane, and formed a scum at the surface of the water. The Fungus then appeared and developed very rapidly.

Massee ('91) says that it is rare, but it has frequently appeared in my cultures of Euglena from various sources, and I suspect that it is to be found very commonly in cultures of Euglena from sewage filter beds. It does not appear so readily on cultures of Euglena obtained from farmyards, but if, as suggested by Kwakine ('86), the cultures are started in a dilute solution of albumen in water, the parasite usually makes its appearance. Its presence is indicated by a greyish appearance of the green scum, and, when it occurs in quantity, by a peculiar roughness on its surface which is very characteristic, and quite different from that brought about by other parasites, of which a considerable number, including many of the Chytridiaceae, occur frequently on Euglena.

The parasite spreads very rapidly. A single cell, with its numerous branching pseudopodia or haustoria, may attack a very large number of individual Euglenae, frequently from thirty to fifty, or possibly even more, and in the early stages of development large sporangia with enormous numbers of zoospores are produced, by means of which the infected area is rapidly extended in all directions. In the course of about six days the colour of the culture changes from greyish green to yellow, and finally, when the Euglenae have been completely or almost completely destroyed by it, the culture becomes dark brown. At this stage the formation of zoosporangia has ceased and large numbers of zygotes in various stages of development will be found.

\section{EFFECT ON EUGLENA.}

The Euglenae are only attacked by the parasite when they are in a rounded-off and encysted state. So long as they are motile, the haustoria are unable to obtain an entry.

The haustorium quickly penetrates the Euglena cell by perforating the cell-wall. It then branches in all directions and soon brings about a complete disintegration of the cell contents. The first effect visible in the cell is that the chlorophyll bodies turn yellow or yellowish green. They then gradually disappear and in their place are found rusty red granules or masses of granules. The protoplasm at the same time becomes absorbed. Then the paramylum grains become broken up and the granules of the eyespot separate from one another. The nucleus and the cell membrane at this stage are still to be seen, but the nucleus is gradually absorbed, and after a long time (several days) the cell-wall also disappears, and the rusty red granules become disseminated in the surrounding liquid. 


\section{Structure of the Thallus.}

The thallus is unicellular and uninucleate. The cells vary much in form and size, sometimes smaller, but frequently larger than the cells of Euglena. In form they vary from a nearly spherical to an elongate shape and are commonly very irregular in outline (Pl. XVI, Figs. I-5 and Pl. XVIII, Figs. 49-55).

The pseudopodia or haustoria which radiate from the cell in all directions are prolongations of the cell-body and continuous with it. The delicate membrane around them is difficult to observe, but in the later stages of development it becomes impregnated by some substance which takes up stain, and is then easily seen on staining with fuchsin. Both Bail ('55) and Nowakowski ('76) call attention to the resemblance of these haustoria to the pseudopodia of certain Rhizopoda. This is certainly very striking, especially in the earlier stages of development ; the young spherical cells, with their delicate haustoria radiating on all sides, look exactly like some forms of the Heliozoa (Figs. $5^{\circ-55}$ ).

The protoplasm of the cell is dense and granular, and contains numerous oil-drops. The pseudopodia show finely granular contents with minute oildrops. The oil is coloured light brown in osmic acid.

The nucleus stains very easily in any of the ordinary nuclear stains. Cover-glass preparations can be made by lowering a cover-glass gently upon the scum at the surface of the water. The scum sticks to the coverglass sufficiently firmly to allow the operation of fixing, staining, and mounting to be carried out without any danger of its being washed off. Or, a small piece of the surface scum of Euglenae is cut off and floated on to a microscopic slide. This is allowed to dry round the edges to attach it firmly to the slide, and is then fixed, stained, and mounted. For the details of cytological structure, microtome sections from material embedded in paraffin in the usual way are desirable.

The structure of the resting nucleus differs somewhat from the normal structure in the higher plants. We find a slightly stainable substance in the form of a more or less spherical mass in the centre of the nucleus, but connected to the nuclear membrane by delicate radiating threads (Figs. 5762). On one side of this is an arc-shaped cap of chromatin which sometimes appears homogeneous, sometimes vacuolar, and sometimes granular (Figs. $I-5$ and 57-62). The slightly stainable mass in the centre looks as if it were a much condensed fine network. All the chromatin of the nucleus is contained in the arc-shaped mass. Somewhat similar nuclei have been described by Percival ('09) in Synchytrium endobioticum. Sometimes this arc-shaped mass is found in close contact with the periphery of the nucleus as shown in Fig. 3, and on passing into the sporangium it becomes flattened against it (Fig. 28). In the course of the nuclear divisions which take 
place in the zoosporangium, a large part of this chromatin mass becomes extruded into the cytoplasm (Fig. 30 ), a small portion only being retained for the formation of the chromosomes.

The nucleus is surrounded by a dense granular mass which stains deeply in nuclear stains (Figs. I-5, 54-58). The structure of this mass is interesting. It consists of a cytoplasmic network, the meshes of which enclose spherical globules of oil (Figs. 55, 57), the knots of the network consisting of deeply stainable irregular granules, which give the characteristic reaction of chromatin, in that they are deeply stainable in nuclear stains, and give a distinct reaction for organically combined phosphorus. It is possible that this chromatin-like substance is concerned in the production of the oil. It appears first in the young zoospore at a late stage in its formation in the zoosporangium, as a dense stainable mass around the nucleus (Figs. 46, 47). It seems to be due to an aggregation of minute stainable granules from the cytoplasm, but may also be partly derived from the nucleus. Chromatin-like substance is constantly extruded from the nuclei at various stages in their development, and notably in the sporangia and zygotes. As soon as the zoospore comes to rest and begins to germinate, this dense mass becomes gradually filled with globules of oil or fatty substance, and is thus transformed into a deeply stainable spongelike granular mass (Figs. 54, 55). During the formation of the zoosporangium this deeply stainable mass, together with the oil, passes into it and becomes broken up and dissipated in the cytoplasm in the form of minute granules.

\section{ZOOSPORES.}

The structure of the zoospore is very simple. At the anterior end, immediately below the single cilium, is a yellow or orange-coloured oil-drop, and below this the colourless protoplasm with a nucleus (Figs. $2 \mathrm{I}, 48$ ). The protoplasm at the posterior end of the spore is granular, and forms a slightly flattened mass which is very conspicuous (Fig. 2I). Nowakowski regards the oil-drop as a nucleus; Zopf takes a similar view, but states that the nucleus owes its strong refractive power to the fact that it contains oil. From observations which I have made on stained specimens at various stages in their development, the oil-drop is found to be in close contact with the nucleus but not inside it (Fig. 48). The zoospores vary very much in size. Nowakowski gives their measurements as $6 \times 3 \mu$ to $\mathrm{I} 3 \times 5 \mu$, and I have found them varying from $5 \times 3 \mu$ to $12 \times 6 \mu$. Even in the same sporangium considerable variation may be found, especially in the sexual sporangia.

The zoospores of Polyphagus are phototactic, and they are thus enabled to make their way to those regions where the host-cells, which are also phototactic, may have accumulated. The mechanism by which the direction of locomotion is effected by the light is not apparent, but it is significant, as I have previously pointed out ('99), that the orange-coloured oil-drop is 
always placed at the end of the zoospore immediately beneath the point of attachment of the cilium and in close contact with the nucleus. It is possible that the light rays absorbed by the oil-drop may be capable of setting up changes in its immediate neighbourhood, possibly through the nucleus, which are capable of reacting upon the cilium in such a way as to exercise a directive influence on its movements.

Immediately the zoospores come to rest they round themselves off and begin to germinate. They increase slightly in size, and pseudopodia appear about $\mathrm{I} \frac{1}{2}$ to 2 hours after they come to rest. The pseudopodia increase in length so rapidly that 3 hours after they begin to form many of them are five or six times the diameter of the cell. The germination follows the same course whether the zoospores are derived from asexual or from sexual sporangia. Figs. 49-53 show the early germination stages of a zoospore.

Stained specimens show that the nucleus and oil globule are in close contact with one another and are surrounded by a deeply stainable chromidial mass (Fig. 48), the peripheral layer of cytoplasm being stained only very slightly. This chromidial mass thins out as it reaches the anterior end of the oil globule, and appears to be continuous with the cilium just at the point where it is given off from the zoospore. In the early stages of the growth of the young thallus, the chromidial mass persists around the nucleus and appears to be directly connected with the pseudopodia (Fig. 54). As development proceeds, the thallus assumes an irregular outline and the chromidial mass becomes alveolate owing to the appearance of globules of oil (Fig. 55).

\section{REPRODUCTION.}

The organism reproduces itself sexually and asexually. So long as there is a fair amount of nutriment in the shape of unattacked Euglena asexual reproduction prevails, but as soon as the nutriment fails, and this happens very soon in an ordinary culture, the sexual organs begin to form. In both methods of reproduction sporangia are formed. In the asexual method the sporangia are produced directly, as outgrowths of the vegetative cells. In the sexual method of reproduction two vegetative cells unite to form a zygote, which subsequently on germination produces a zoosporangium similar in appearance but usually smaller than that formed asexually.

The asexual sporangium first appears as a small spherical outgrowth on the vegetative cell. This gradually increases in size, and the protoplasm and oil-drops pass into it until nothing is left in the parent cell but a few delicate strands of protoplasm and one or two small oil-drops. From a series of observations made on two different sporangia, the rate of growth in length during the earlier stages appears to be about $.005 \mathrm{~mm}$. per hour, but in the later stages it varies very considerably, being often very much 
more. When all the protoplasm and oil-drops have passed into the sporangium it is cut off from the parent cell by a transverse partition which begins to form at the periphery and gradually extends all across between the cells.

In the germination of the zygote, the outer spiny wall bursts and a spherical protrusion of the inner membrane projects through it and develops in the same way as just described for the asexual sporangia. The protoplasmic contents of the zygote pass into this completely, and the sporangium is then cut off by a transverse wall. During all the subsequent stages of its development it remains attached to the empty zygote, just as the asexual sporangium remains attached to the empty vegetative cell.

The changes which take place in the contents of a sporangium leading to the formation of the zoospores were followed out in several instances by continuous observation under the microscope, both in the asexual and in the sexual sporangia. These are the same in all essential details in both cases, and as Nowakowski has given an account, although not a very complete one, of the formation of zoospores in the asexual sporangia, I will confine myself mainly to a description of the changes which take place in the sexual sporangium (see p. 186).

\section{Cysts.}

These are spherical cells, resembling the smooth-walled zygotes in appearance, containing each a single nucleus. They differ from the zygotes, however, in the presence of well-developed absorbing filaments and in the simpler structure of their membrane. In agreement with Dangeard ('00), I find that the cysts are simply ordinary vegetative cells which become surrounded by a thick membrane and enter on a resting stage.

The formation of cysts takes place very readily when the parasite is abundant and the supply of Euglenae limited. The cysts are then developed in large numbers and often crowded together. Each cyst contains a single nucleus surrounded by chromidia. The cysts germinate easily when placed in fresh cultures of Euglenae, and produce zoosporangia similar to those produced by the ordinary vegetative cells, but usually much smaller.

\section{FORMATION OF ZYGOTES.}

The zygote is formed by the fusion of two ordinary vegetative cells, which, instead of producing zoosporangia, become transformed into gametes. The gametes are usually different in size, the smaller one functioning as the male, the larger one as the female (Figs. I-5). Nowakowski observed ('76) two different methods of zygote formation, resulting in the one case in the production of a smooth-walled zygote, and in the other of a zygote with 
a spiny wall. Both may be found in the same culture, but the spiny form seems to be the normal one, and is produced under the more favourable conditions of food supply in the early stages of a culture, the smooth form being produced, sometimes in great abundance, during the later, less favourable conditions. In both cases the gametes are placed in contact with one another by a delicate pseudopodium-like process, which is put out from the male gamete. These copulating pseudopodia are of varying length, sometimes very short (Fig. 4), at other times extending to a considerable distance before they can reach the female gamete (Fig. I). Whether there is any definite attraction between the two gametes, or whether it is merely a chance encounter, I have not been able to determine. The copulating pseudopodia do not differ in any respect, except possibly that of extreme length in some cases and absence of branching, from the ordinary haustoria which penetrate the Euglenae.

In the case of the spiny form the zygote is produced by the swelling of the apex of the pseudopodium near its point of contact with the female cell (Figs. I-5). The smooth-walled zygote is formed, on the other hand, according to Nowakowski ('76), as a globular outgrowth from the female cell just where it comes into contact with the male pseudopodium. I have not been able to observe this second method of zygote formation, although I have seen the production of both spiny and smooth-walled zygotes. So far as my observations go, the zygotes are formed in both cases by a swelling of the apical portion of the male pseudopodium in contact with the female cell. Dangeard also ('00), who has made observations on the formation of the smooth-walled zygotes, describes them as swellings on the pseudopodium of the male cell, and he further remarks: 'We have seen nothing which allows us to postulate with Nowakowski a different manner of formation for these two kinds of zygotes.'

The following observations on the formation and maturation of the zygote refer to the spiny form. Immediately following the appearance of the zygote, the protoplasmic contents of the male cell pass through the delicate pseudopodium into the zygote (Fig. 5). A perforation appears in the wall between the young zygote and the female cell (Figs. 3, 5), and the contents of the latter pass through it into the zygote (Figs. 59, 60). ${ }^{1}$

The zygote is then cut off by partition walls from the remains of the two original gametes. The whole process, from the time of the first appearance of the swelling on the pseudopodium to the complete separation of the zygote, takes about twelve hours or less. The contents of both gametes include a large number of oil-drops, and in some cases the nuclei of the living cells can be clearly made out.

1 In all the cases which I have observed, the male nucleus first of all passes into the zygote, then the female nucleus, but Dangeard ('00), in describing the formation of the smooth-walled zygotes, states that the female nucleus ordinarily passes in first, then the male. 
The examination of stained specimens shows that the nuclei of the fusing gametes have exactly the same structure as those of the ordinary vegetative cells. The male nucleus is, however, usually smaller than the female, and contains less chromatin.

The passage of the male nucleus through the pseudopodium is of considerable interest, but the mechanism by which it is brought about is obscure. The delicate pseudopodium is much smaller in the diameter of its lumen than the nucleus, and must therefore offer a certain resistance to its passage. The force which drives the nucleus along may possibly be derived from a combination of the turgescence of the male cell with the vacuum caused by the increasing expansion of the young zygote at the end of the pseudopodium, or it may be that some attraction is exerted by the female cell upon the protoplasm of the male cell. The delicate wall of the pseudopodium is probably very elastic, and although I have never seen a nucleus during its passage through the pseudopodium, it is clear that the wall expands sufficiently to allow the nucleus to pass through it readily. There is no evidence that the nucleus has any motive power of its own to enable it to force its way along the pseudopodium, and it does not seem likely that the delicate wall of the pseudopodium is capable of a rhythmical expansion and contraction sufficient to bring it about.

In the zygote the two sexual nuclei come into contact with each other (Fig. 6I). Then the smaller male nucleus begins to increase in size, probably at the expense of food material in the zygote, and this continues until it is almost exactly similar in size to the female nucleus. The two nuclei then move apart to opposite sides of the cell (Fig. 62).

When the zygote is first formed it frequently contains, scattered through the cytoplasm, a number of deeply stainable granules, which are probably the remains of the dense granular masses derived from the gametes at the time of fusion (Figs. 6I, 62). Dangeard ('00) has noticed these and called them coenospheres. As the zygote develops they gradually disappear, and at the same time the oily contents of the cytoplasm increase in quantity to form a supply of reserve food material for use at a later stage.

The two nuclei then undergo considerable changes. Chromatin material in the form of amorphous masses or granules is extruded from them into the cytoplasm, and they become smaller and lose to some extent their capacity for stains (Figs. 63-66). The extruded granules stain very deeply in nuclear stains and give a strong reaction for organically combined phosphorus. They are obviously of the nature of chromidia, similar to those described by Hertwig ('07) and others in the Protozoa. They form conspicuous elements in the zygote at this stage, and become massed together into two more or less distinct groups (Fig. 67), one being produced by each nucleus. Shortly after their appearance they fuse together into a single dense mass in the centre of the zygote (Figs. 68-73). The two 
nuclei remain visible through all the subsequent stages of development either at the periphery of the chromidial mass or slightly embedded in it.

The presence of these well-marked chromidia in Polyphagus recall so strongly the appearances presented by the cells of many Protozoa that I propose to discuss very briefly the present state of our knowledge of chromidia.

\section{CHROMIDIA.}

Hertwig ('02) designated as chromidia the discrete chromatin, derived from the nucleus, which is found in the form of granules or more or less branched strands or networks in many Protozoa. They were first recognized in Actinospherium, in which they occur abundantly during particular states of metabolism, as in over-feeding or starvation.

The occurrence of diffused chromatin in the cell, and the occasional disappearance of all other traces of nuclei, suggested to Hertwig that in certain organisms the diffused chromatin might entirely replace the true nucleus. This is probably the case in the Bacteria and Cyanophyceae. In these forms the nucleus as a histologically defined organ is wanting, but chromatin in the form of chromidia is diffused through the cytoplasm.

At the present time a good deal of confusion exists as to the precise nature and significance of chromidia. Many authors regard all deeply stainable granules in the cytoplasm, whether derived from nuclei or not, as chromidia, in which case the term has no real significance, and certainly not the significance which, if I understand him correctly, Hertwig meant to convey when he first made use of the term 'chromidien'. The term chromidia should, in my opinion, be strictly reserved for those granules that can be shown to have been derived from nuclei or which take the place of the nucleus. The singular of chromidia is chromidium, which obviously means a single granule, and not the mass of granules to which it has been applied by some observers, in a manner which strikes me as very confusing (cf. Minchin, I9I 2, p. 65). Minchin suggests the term chromidiosomes for the separate particles which Hertwig called chromidia, but it seems to me that this is unnecessary if we use the original term properly in Hertwig's sense.

So far, it appears that four distinct categories of chromidia can be recognized:

I. Those which definitely represent the nucleus of the cell and are the only nuclear structure present. Such occur in some Bacteria and possibly Cyanophyceae.

2. Those which are formed at certain stages in the life of a cell by the breaking up of a nucleus into granules, which are distributed in the cytoplasm, but which are capable of being re-formed into nuclei. These may be found in some Protozoa.

3. Those which are extruded from the nucleus for the purpose of 
metabolism and are finally used up and not reabsorbed into the nucleus or reconstructed into nuclei. They are found in egg-cells of various kinds and probably to some extent in all cells in active growth and division. The chondriosomes and chromatin structures of similar nature derived from nuclei would also be included here.

4. Those which are extruded from the nucleus, or cut off by division for purposes of metabolism and vegetative growth, but which are at once constituted into nucleus-like structures more or less clearly defined in the cytoplasm. The macro-nuclei of Protozoa, the granular structure of Polyphagus, and possibly the so-called coenocentra and perhaps pyrenoids are instances.

So far as their functions are concerned, we thus see that we have two main types of chromidia, one possessing a purely vegetative function, and the other a generative or reproductive function. The following table shows the general relationship of the four categories given above :

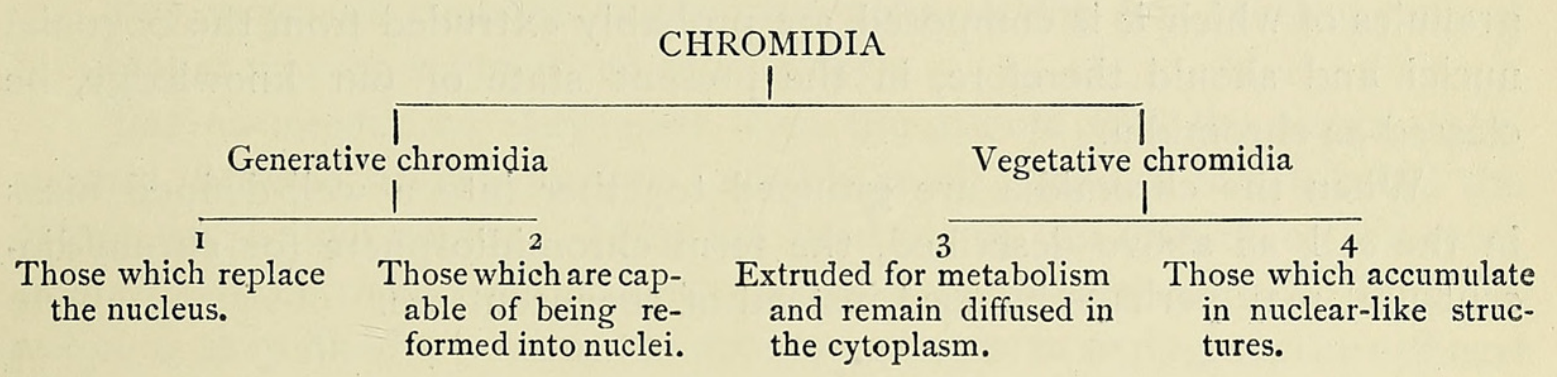

Goldschmidt ('04) proposes the terms chromidia and sporetia for the vegetative and generative chromidia respectively, and Mesnil ('05) suggests trophochromidia and idiochromidia. Minchin (p. I 50 ), however, considers that the term chromidia should be retained 'to denote simply extranuclear particles of chromatin, and to qualify the term by the adjectives vegetative and generative when required'. These terms are sufficiently distinctive, but it must not be forgotten that those chromidia which definitely replace the nucleus, as in Cyanophyceae and Bacteria, have both generative and vegetative functions.

In Polyphagus, the granular mass which we regard as chromidial arises from the nucleus, and is definitely extruded for purposes of metabolism. In the zoospores and in the early stages of the development of the thallus this chromidial mass is homogeneous or finely granular (Figs. 48, 54). Later, it exhibits a vacuolated structure, owing to the formation of globules of oily substance in the alveoli (Fig. 55). This fatty substance, which is formed as a reserve food material for use during subsequent growth and development, appears to be produced largely at the expense of the chromidia.

Chromidia are present at all stages in the life-cycle of Polyphagus, and are constantly being reinforced, as they are used up, by fresh extrusions from the nuclei at various stages in the nuclear cycle. The granules found 
scattered in the cytoplasm of the zygote during the early stages of development, which Dangeard ('00) calls coenospheres, must also be regarded as chromidia, and it is interesting to find that Dangeard considers that they are of a fatty nature. The chromidia of Polyphagus are strictly comparable to the granular mass which occurs in the oospores of Cystopus and Peronospora, the so-called coenocentrum.

The function of the coenocentrum is not clearly understood. When first discovered, I thought its purpose was to act as a kind of attractive centre to bring the two sexual nuclei together in the middle of the zygote. This view has generally been accepted, but from recent investigations I am not satisfied that it is the correct one. It appears to be much more nearly concerned with the vegetative activities of the oospore than with the fusion of the nuclei, and although it may not actually possess the characteristics of a fatty body, as Dangeard suggests ('00), it certainly seems to be the centre of formation of the oily reserves which accumulate in the oospore. The granules of which it is composed are probably extruded from the oogonial nuclei and should therefore, in the present state of our knowledge, be classed as chromidia.

When the chromidia are grouped together into a well-defined mass in the cell, as above described, the term chromidiosphere (or chromidiocentrum) may perhaps be used instead of coenocentrum.

\section{Chromidial Fusion.}

Chromidia as definite structural organs in the cell are of frequent occurrence in the Protozoa, and it is interesting to find them so well marked in Polyphagus and presenting such close resemblances to the chromidial masses of the Protozoa. Some of the figures of chromidia in Pelomyxa given by' Bott ('07), for example, resemble to an extraordinary degree those which I have given of Polyphagus. The fusion of chromidia in the zygote of Polyphagus also resembles in many respects that which takes place in many Protozoa, but it is of a much simpler type. In the Protozoa the fusion of the chromidia, or chromidiogamy, as it is sometimes called, is one of the stages in a complex nuclear cycle during which the original nuclei degenerate and new ones are reconstructed out of the chromidia. In Difflugia urceolata, for example, the two sexual cells each with nucleus and chromidia come into contact and the contents of one pass into the other. The chromidia then fuse and the nuclei ultimately degenerate, new nuclei being formed from the chromidial mass. Again, in Arcella (see Minchin, p. I48) each of the fusing cells contains a nucleus and chromidia. The contents of one cell pass into the other and the primary nuclei degenerate, then 'break up into a fine dust of chromatin particles and become intimately commingled'. 'When this process is complete, the protoplasm with the chromidia becomes again distributed between the two 
cells and the two conjugants separate. Then in each individual secondary nuclei are formed from the chromidia.' Somewhat similar phenomena occur in Centropyxis aculeata, according to Schaudinn ('03), where the nuclei degenerate and the sexual nuclei are derived from the chromidia.

In Pelomyxa, according to Bott ('07), chromidia are extruded by the nuclei into the cytoplasm. From these chromidia secondary nuclei arise, out of which, by a complex process of extrusion of chromatin and subsequent division, the nuclei of the gametes are formed.

In Polyphagus the nuclear cycle is not so complex, and the primary nuclei do not degenerate but remain in close contact with the chromidial mass. The chromidia appear to be formed for the purposes of metabolism only and gradually disappear, or lose their stainable characteristics, as the zygote matures. The two small generative nuclei remain separate until the sporangium is formed, when they pass into it along with the other contents of the zygote and fuse together to form the primary nucleus of the sporangium.

The cycle of changes in the chromidia during the development of Polyphagus may be summarized as follows:

The chromidia, as they pass from the zygote into the sexual sporangium, become broken up into invisibly small granules which cause the cytoplasm to stain deeply. They are used up in the growth of the sporangium and are reinforced by fresh masses of chromatin extruded from the nuclei as they divide. When the zoospores begin to segregate, the diffused chromatin gathers round each nucleus and ultimately forms the deeply stainable granular network found around the nucleus in the germinating zoospore and the fully developed vegetative cell. When the asexual sporangium is formed, the granular network again breaks up and is disseminated through the cytoplasm, to concentrate again round the forming zoospores. This process is repeated during successive asexual generations till a zygote is formed again. The two nuclei in the zygote are very large and contain a great deal of chromatin, which is extruded from them to form two masses of granules (chromidia) that subsequently fuse together into a large central mass which is visible for some time in the mature zygotes. Just at the time the zygotes are about to germinate, this granular mass loses very largely its capacity for stains, and on passing into the sporangium, becomes diffused in the cytoplasm, and the cycle of changes then repeats itself.

\section{Germination of the Zygote.}

The two kinds of zygote, the spiny and the smooth-walled forms, may be found, as Nowakowski states, in the same culture. The germination of the smooth-walled form has been observed by Nowakowski, but not the spiny form. He found that germination takes place about a month after the formation of the zygote. The large oil-drops become reduced in size, or may break up into smaller drops; the outer wall bursts 
and the protoplasmic body grows out into a sporangium in which zoospores are formed similar to those formed in the asexual sporangia.

I have made many attempts to obtain the germination of the spiny form, but have only once succeeded. A culture containing a large number of mature zygotes had been kept under continuous observation for five months, May to November, without any change taking place. Suddenly, however, at the beginning of November, on a dull foggy morning, I noticed that very active germination was in progress, and I was fortunate enough to be able to follow out the whole process under the microscope. I have tried many times since to induce the germination of zygotes in my cultures, but, notwithstanding that I have tried all sorts of methods and placed the mature zygotes under varying conditions, I have never been able to repeat my observations.

The process of germination takes place exactly as described by Nowakowski for the smooth-walled form, and, except for the necessary rupturing of the outer spiny wall of the zygote, the growth of the sporangium and the changes which take place in it leading to segregation of the zoospores are, as already mentioned, similar in all essential details to those which occur in the formation of the asexual sporangia.

The observations about to be described began at $8.15 \mathrm{a} . \mathrm{m}$. and were continued for more than twelve hours until the zoospores escaped. The first indication of germination is the rupture of the outer wall of the zygote and the protrusion of a delicate hyaline sphere, consisting of a quantity of hyaline or slightly granular protoplasm, surrounded by a very delicate membrane (Fig. 6). This slowly increases in size; fatty granules of irregular shape pass into it, together with the granular protoplasm (Figs. 7 , $8,9)$. The fatty masses begin to break up at once into smaller granules, and finally into minute particles which show a tendency to aggregate into short irregular rows (Figs. IO, I I), giving the protoplasm a filamentous appearance, as described by Nowakowski. At this stage the protoplasm becomes vacuolar, and a delicate cell-wall appears separating the sporangium from the nearly empty zygote. Very few oil-drops are now to be seen, and the filamentous structure becomes more apparent, especially in surface view. A little later the larger oil-drops completely disappear and the protoplasm now shows the filamentous arrangement of the minute oil-drops all through (Fig. I2). The oil granules then become rearranged to form a more regular network surrounding vacuolar spaces which gradually become more numerous (Figs. I3, I4). The minute oil granules at the same time become more distinct and tend to separate from one another. At 2.30 p.m. the vacuolar spaces had become still more numerous, with the oil granules arranged regularly around them, presenting the appearance in optical section of rings of granules. At 2.45 these rings of granules began to assume an irregular appearance and then began to fuse together 
again into larger drops. This went on rapidly, so that by 3 o'clock the contents of the sporangium had quite a different appearance (Fig. I5). These larger drops then run together in twos and threes (Fig. I6), and at 4 p.m. these groups had fused together to form a number of oil-drops nearly equal in size and fairly equally spaced (Fig. I7).

At this stage the segregation of the zoospores begins. The granular protoplasm containing yellowish oil-drops of different sizes becomes aggregated into masses separated by delicate lines of cleavage (Fig. I8). ${ }^{1}$ These spore-origins may be as shown in Fig. 18 , or they may be more irregular in size and shape, as shown in Fig. 22, and the lines of demarcation may disappear and reappear again. Very soon, however, the spore-origins contract slightly and become clearly marked off from one another. At about this stage a movement of rotation becomes visible in the sporangium and the spore-origins appear to move slowly over one another. This is probably due to the gradual rotation of the whole protoplasmic contents of the sporangium, as described by Hartog ('87, '88) in species of Saprolegnia. In a few minutes the lines of demarcation become invisible and the sporeorigins seem to fuse. The explanation to be offered of this apparent fusion is probably that the cleavage of the protoplasm begins in the centre of the sporangium and gradually extends towards the periphery. At the moment when the lines of cleavage reach the periphery and the outer layer of the cytoplasm is ruptured, thus completely separating the spores, there is a loss of turgescence and consequent contraction in the sporangium, and it is this, and possibly a swelling of the young spores also, which brings about the apparent fusion of the spores (cf. Hartog, '87, '88, and Rothert, '87). For a short time the lines of cleavage remained invisible; the oil-drops underwent further fusion, and at 5 p.m. were observed to be moving slowly backwards and forwards. At $5.45 \mathrm{p} . \mathrm{m}$. fine lines again appeared dividing the protoplasm into smaller polygonal masses, each of which contained one oil-drop, and at 6 p.m. these protoplasmic masses had become completely separated from one another although still compressed into a polygonal shape (Fig. I9), but they at once commenced to move slowly, and at 6.5 p.m. were observed to elongate (Fig. 20) and take on the form of ripe spores. The oil-drop was now at one end of the spore. At 6.8 p.m. the apical portion of the sporangium wall gradually became thinner, and finally an opening was formed and the zoospores came out (Fig. 2I). As they come out they swim away, but some of them have their cilia entangled among those still in the sporangium and are seen at the opening of the sporangium for some time making short jerky movements, apparently trying to tug their cilia away. After a little time they

1 This stage and those which follow are very interesting, and show slight variations in different sporangia. Thus Figs. 22 to 25 are from an asexual sporangium, in which 64 spores were produced, and may be compared with the same stages of the smaller sexual sporangium in which there were only 32. As a rule, the apparent fusion of the spore-origins is more pronounced in the larger sporangia. 
succeed, and swim rapidly away. The last two or three zoospores left in the sporangium sometimes find some difficulty in getting out, especially if the sporangium is a large one ; they swim about inside it, with apparently no sense of direction, for several minutes sometimes (Fig. 2 I), but ultimately they find the opening and escape. In one case it took about five minutes for a sporangium with about 128 spores to empty itself, except for the three last spores, which were apparently unable to find their way out, and the last one of the three only succeeded in getting out at the end of $12 \frac{1}{2}$ minutes from the time the sporangium opened. In some cases the zoospores remain for a few seconds near the opening of the sporangium in a quiescent condition; then with a slight jerking movement, as if to disentangle their cilia, they swim away. After moving about rapidly for about twenty minutes the spores come to rest for a few seconds now and then. They then begin to move about in a very jerky fashion, often resting for a few seconds. By 7.Io p.m. only three could be observed in the neighbourhood of the empty sporangium: all the others had moved away completely from the field of view. At 7.I 5 I observed these three settle down, but they retained their cilia and remained in an intermittent quivering state for some time. At 8. Io they had lost their cilia and were quite still and beginning to round themselves off into a spherical form (Fig. 49).

The sporangia vary very considerably in size, and the variation in the number of zoospores produced is equally great. Nowakowski found in one case, in an asexual sporangium, that only two zoospores were formed, and I have constantly found sporangia in which from eight to sixteen zoospores only were formed. This variation in the number of zoospores appears to depend upon the amount of nutriment which can be stored up in the zygote, or upon the number of Euglenae attacked by a single individual. For, as I have constantly observed, the asexual sporangia are larger at the beginning, when the nutriment is more abundant, than at the end of an attack when the nutriment has been exhausted. The number of zoospores produced in the asexual zoosporangia is as a rule much larger than those produced in the sexual zoosporangia.

In stained specimens it is found that preparatory to germination the chromidial mass in the zygote loses to some extent its capacity for stains and is much less conspicuous (Fig. 74), allowing the two nuclei to come more clearly into view (Fig. 75). On germination, whatever is left of it passes with the two nuclei (Figs. 76-8I) into the sporangium and there becomes disseminated throughout the cytoplasm. The two nuclei, which now stain more deeply but are still very small and quite unlike the primary nucleus of the asexual sporangium, come into close contact with one another (Figs. 79-8I) and apparently fuse (Fig. 82). The exact process of fusion has not been observed, and it is quite impossible to say whether the chromosomes fuse together or become merely intermingled, to separate later 
into two groups. The structure of the nuclei at the fusion stage has not been clearly ascertained, but there are indications that previous to fusion the chromatin mass breaks up into granules, probably chromosomes (Figs. 80, 8I). The subsequent stages of nuclear division in the sexual sporangium seem to follow the same order as in the asexual sporangium, and similar changes can be observed in the final segregation of the zoospores, but the details have not been followed out in stained specimens. Fig. 83 shows a nucleus in what appears to be an early division stage; Fig. 84 shows the division of the primary nucleus of the sporangium into two, and Fig. 85 a late stage in the division of two nuclei. The number of chromosomes in each daughter nucleus could not be counted, but they appeared to be not greater than ten.

\section{NuClear Division.}

Nuclear division takes place only in the sporangia, never in the vegetative cells, gametes, or zygotes. The single large nucleus (Figs. 26-28) which enters the asexual sporangium from the vegetative cell at once divides into two, then four, eight, sixteen, thirty-two, sixty-four, \&c., until a very large number are formed, sometimes several hundred. The number produced varies within very wide limits from two or four in very small sporangia to several hundred in the larger ones.

I have not been able to observe the process of division of the primary nucleus of the sporangium, but in all the later stages it is mitotic, and is probably the same, therefore, in the primary nucleus. The spindle appears inside the nucleus before the wall is broken down (Figs. 30, 33, $3^{8-40}$ ), and is apparently formed out of the lightly stained chromatin mass which is found in the middle of the nucleus in contact with the chromatin cap. The chromosomes are about ten or twelve in number and very minute (Figs. 30, 33, 38). Only a very small portion of the large and dense chromatin mass is used up in their formation; the rest forms a thick peripheral layer on the wall of the nucleus (Figs. 30-39), which is visible during all the stages in the prophases of division, and is finally set free in the cytoplasm to be used up in the further growth of the sporangium.

Soon after the appearance of the spindle the nuclear wall at the poles of the nucleus disappears (Figs. 33, 40), and the rest of the nuclear wall contracts and becomes flattened (Fig. 39). The two poles of the spindle protrude slightly through the polar openings into the cytoplasm. At this stage centrosome-like structures become visible at the two poles (Fig. 39). The daughter groups of chromosomes then separate to the opposite poles of the spindle (Figs. 4I, 42), the nuclear wall disappears entirely, and the peripheral mass of chromatin which was in contact with it contracts into a more or less globular mass, which is left lying in the cytoplasm (Figs. $3 \mathbf{I}$, $34,35,42)$. The chromosomes become aggregated at the periphery of the 
newly constructed daughter nuclei in close contact with a lightly stained substance (Figs. 3r, 44), consisting of a very fine network which almost completely fills up the rest of the nuclei. A few delicate strands remain for a short time between the daughter nuclei (Figs. 35, 43), but these soon disappear and the nuclei are left free in the cytoplasm (Fig. 44).

When the nuclear divisions are completed the segregation of the cytoplasm around the separate nuclei to form the zoospores begins. Irregular splits appear throughout the whole of the sporangium, which soon separate off distinct masses each with its own nucleus (Fig. 45). Then the oil-drops begin to fuse together to form the large oil-drops shown in Fig. 46. These come into close contact with the nuclei, one being found in each spore origin. Then a condensation of fine granular deeply stainable substance begins to aggregate around the nucleus, and partly enclosing the oil-drop and the cytoplasm immediately around, becomes vacuolar and no longer stains deeply (Fig. 46). It is just at this stage that the sporangium becomes homogeneous again by an apparent fusion of the spore origins. Soon after this fusion delicate lines of demarcation again appear, separating the spores, and delicate cell-walls make their appearance around each spore, which now rounds itself off and then become slightly elongated (Fig. 47) preparatory to escaping from the sporangium.

\section{Cytology OF OTHER Forms.}

The only other members of the Chytridiaceae in which serious attention has been given to the cytology are various species of Synchytrium, Olpidiopsis, and Olpidium. In Synchytrium numerous curious and abnormal phenomena of nuclear division have been observed. Thus Dangeard ('89, '90) and Rosen ('92) both describe a form of direct nuclear division in the primary nucleus of Synchytrium Taraxaci, but they also found true mitosis at later stages. On the other hand, F. L. and A. C. Stevens ('03) found that in $S$.decipiens, $S$. fulgens, and $S$. papillatum the division of the primary nucleus is mitotic, whilst it would appear from the observations of Stevens ('07), Griggs ('09, \&c.), Kusano ('09), and Bally ('11) that the later divisions are very variable, being sometimes mitotic, sometimes amitotic. Griggs mentions ('09) that amitotic spiremes are frequently indistinguishable from mitotic spiremes, and that amitosis by constriction and also by gemmation may occur in the same cyst. Stevens ('07) describes some remarkable nuclear phenomena in the later stages of Synchytrium which appear to be without parallel in the cytology of any plant or animal yet known, and the significance of which is inexplicable. F. Griggs ('09) describes some peculiar changes leading to the separation of portions of the karyosome (nucleolus) of the primary nucleus either by migration or dissolution of nuclear membrane. Each fragment becomes surrounded by a vacuole and a new nucleus is formed which later undergoes mitosis, and its descendants form 
spores. Percival ('09) also gives an account of a remarkable nuclear cycle in the production of the thin-walled cells of Synchytrium (Chrysophlyctis) endobioticum. 'With the beginning of the reproductive stage, the chromatin of the nucleus (primary nucleus) often becomes associated with the linin threads. The nucleolus becomes vacuolated and loses its staining power; at the same time the nucleus shrinks and soon disappears entirely, the chromatin contained within it being found in the form of very distinct "chromidia" scattered through the cytoplasm of the parasite; round the chromidia small vacuoles appear, and nuclei arise at these points.' No primary nucleus was found to undergo recognizable mitotic division, but undoubted mitosis occurs in the minute secondary nuclei (p. 443). Kusano ('12) states that in Olpidium Viciae 'the nuclei of the sporangium multiply during the vegetative or growing phase by an amitotic-like division and during the reproductive phase by mitosis.'

The very small portion of chromatin which is required for nuclear division, the minuteness of the chromosomes, and the prominence of the extruded nuclear material render the observation of the various stages of nuclear division extremely difficult, and it may well be, especially in Synchytrium, where the resting nucleus is so large and the dividing stages so small (Stevens, '07), that mitotic nuclear divisions have been overlooked. In any case, seeing the numerous discrepancies in the descriptions given by various observers, and that both in Olpidiopsis, as Barrett ('12) has recently shown, and in Polyphagus the nuclear divisions are normally mitotic throughout, with well-marked spindles and chromosomes, it is very desirable that all these abnormal nuclear divisions should be further investigated.

Kusano's account of the cytology of the zygote of Olpidium Viciae is extremely interesting and presents many points of comparison with my own observations on Polyphagus. The two nuclei of the zygote occupy a peripheral position, usually opposite each other. After it has attained its maximum growth chromatin is extruded into the cytoplasm, partly by a process of budding of each nucleus and partly by the extrusion of nucleoli. This chromatin accumulates in the central region of the zygote in the form of a chromidial network, and is deeply stainable. At a later stage the stainable substance occupies the central portion of the zygote as large globules which look like oil-drops. At a still later stage a dissolution of the stainable substance takes place and the cytoplasm appears homogeneously granular, being hardly stainable. Fusion of the nuclei does not take place until shortly before germination. Kusano mentions that cytologically the Fungus shows a certain resemblance to the Protozoa or the Plasmidiophoraceae. 


\section{The Relationship of Polyphagus to other Forms.}

The Chytridiaceae have not been very exhaustively investigated, and very few complete life-histories of them are known. But we have sufficient information concerning various members of the group to show that sexual reproduction may vary from the simple direct fusion of motile gameteszoospores-to the copulation of non-motile gametes which may be either uninucleate or multinucleate and which show clear transitions to the methods of sexual reproduction in the higher groups of the Fungi.

The copulation of motile zoospores has been described by Fisch ('84) in Reesia and by Sorokin ('89) in Tetrachytrium. The cytology of these forms is unknown. Kusano ('12) has, however, shown that in the new species, Olpidium Viciae, which he has discovered, binucleate cells are formed by the copulation of motile uninucleate zoospores. Griggs ('10) had previously described a new genus, Monochytrium, which in some respects resembles Reesia (Atkinson, Bot.Gaz., xlix, I9I0) and bears some resemblance to the species described by Kusano, the zoospores of which penetrate the cells of the host (Ambrosia artemisiaefolia) and there become amoeboid; some of the amoebulae then unite in pairs to form binucleate zygotes.

In Zygorhizidium Willei, according to Loewenthal ('05), the gametes are uninuclear and are equivalent to sporangia. They are placed in contact with each other by a copulating tube put out from the smaller, male gamete, the contents of the latter then passing over into the female, which thus becomes the zygote.

In Olpidiopsis also it is probable, according to Barrett ('12), that the gametes are equivalent to sporangia. Unlike Zygorhizidium, however, the gametes are multinucleate and the sexual nuclei probably fuse in pairs, presenting thus an analogy with Cystopus (Albugo) Bliti.

In its general structure and life-history Polyphagus is obviously associated with Zygorhizidium, and the cytological structure of these two forms, together with that of Olpidiopsis, clearly indicates the connexion of the Chytridiaceae with the Oomycetes. But Polyphagus also has some relationship with Zygochytrium, a form which possesses a well-marked Chytridiaceous sporangium, but is connected with the Mucorineae through its Mucor-like formation of zygospores.

This brief summary shows, therefore, that Polyphagus forms a very obvious link between Zygochytrium and Zygorhizidium, and that there is clearly a progressive sexual series from Olpidium and Monochytrium leading on the one hand to the Mucoraceae through Polyphagus and Zygochytrium, and on the other to the Oomycetes through Zygorhizidium, Polyphagus, and Olpidiopsis.

But Polyphagus, and possibly other members of the Chytridiaceae also, shows some relationships with the Protozoa. Thus, in its general structure, 
Polyphagus is not unlike the common sun animalcule, Actinophrys sol. Many characteristics are common to both: the uninucleate thallus, the radiating pseudopodia connected with, or arising close to, the nucleus, and the vacuolate condition of the peripheral cytoplasm.

In other respects also, as in the peculiar structure of the nucleus and the extrusion of chromidia, Polyphagus shows affinity with the Protozoa.

It is not my purpose here to discuss these relationships, but I cannot help feeling that, the more we learn of the general structure and lifehistories of the Rhizopoda (Sarcodina) and the Chytridiaceae, the more apparent it becomes that the attempt to derive the Chytridiaceae 'from the higher Phycomycetes by degeneration through parasitism' (see Atkinson, '09) is an unsatisfactory solution of a difficult problem, and that in discussing their phylogeny we must take into account the evidence for their possible origin from Protozoan-like ancestors, as Dangeard has maintained ('01), and their development along a progressive line of evolution.

\section{Theoretical Considerations.}

The study of the nuclear cycle of Polyphagus affords clear evidence of the dual nature of the nucleus, and perhaps throws some light upon the delayed nuclear fusions and the double nuclear fusions observed in the sexual reproduction of some of the higher groups of the Fungi.

That nuclei have both somatic and generative functions is well known, and Schaudinn ('03) suggested that these two functions reside in two distinct parts of the nucleus and that each cell is therefore in a sense binucleate. Goldschmidt ('04, '05) put this in an extreme form when he brought forward the definite hypothesis that every cell is essentially binucleate and possesses a somatic nucleus with metabolic functions and a propagative nucleus with generative functions. In the Infusoria it has long been known that these two elements are differentiated in the cell as a macro-nucleus and a micro-nucleus, but in other organisms they are united in a single structure which he calls 'amphinucleus'. In Polyphagus it seems quite clear that the nucleus has this dual structure to the extent that the chromidia represent the vegetative or somatic element and the small nuclei, left after the extrusion of the chromidia, the generative element. This is not, however, sufficient to warrant the conclusion that the chromidia owe their existence to the activities of a somatic nucleus which has an individuality of its own apart from a generative nucleus.

The double fusion which takes place in the life-cycle of Polyphagus is clearly bound up with this dual function of the nucleus, the chromidial fusion in the zygote promoting vegetative growth, whilst the nuclear fusion in the sporangium precedes the formation of the spores. The importation of two nuclei into the zygote appears therefore to be 
primarily for the purpose of increasing its vegetative activity, and the fusion of the generative nuclei is apparently not essential to the maturation of the zygote, but seems to be required for the production of the zoospores.

The obvious explanation that may be given of this is that the zygote is essentially a resting cell in which large quantities of food in the shape of fatty substances and glycogen are stored up in order to tide over a period of rest and to afford food material for the growth of the sporangium which will ultimately be produced, and that for this purely vegetative development the vegetative portions only of the nucleus are required.

This is also very clearly shown in the Uredineae; but here, instead of a resting stage, a long series of vegetative cell divisions is interposed between the cell fusion and the nuclear fusion. The cell fusion, or, as Blackman calls it, 'vegetative fertilization', takes place here by a sexual process in the aecidium, the contents of one cell passing over into the other. The two nuclei come together, but do not fuse. During the long series of vegetative divisions which intervene between the germination of the zygote, or what represents the zygote, and the germination of the teleutospore, they remain separate and divide continually by conjugate division. In the teleutospore the direct descendants of these two nuclei fuse.

The binucleate phase of the Uredineae is commonly regarded as a sporophyte in which the cells contain $2 n$ chromosomes. But inasmuch as the nuclei remain separate all through, it is plain, as Harper points out ('10), that the nuclear fusion is unnecessary so far as the sporophyte is concerned, and that its vigour and adaptability are not dependent upon the union of the parental chromosomes into a single nucleus. But as soon as the time arrives for the actual reproductive organs to be formed, the fusion takes place. The process of conjugate division in the Uredineae is accompanied by the extrusion of nucleolar chromatin which is probably homologous with the chromidia of Polyphagus.

The Hymenomycetes may be brought into line with the Uredineae, for although there appears to be no true sexual fusion, the cells of the hymenium become binucleate, probably by a process of autogamy, similar to that which probably takes in the simpler forms of the Uredineae, and the binucleate condition persists until the formation of the binucleate basidia, in which the two nuclei fuse.

The general conclusion at which we arrive, therefore, is that when the sexual cell fusion is followed by a period of rest, as in Polyphagus, or by a series of vegetative cell divisions, as in the Uredineae, there is no necessity for any nuclear fusion, but that as soon as the reproductive spores are to be formed, the fusion takes place and completes the sexual fusion.

Here we are met with the anomaly in the life-history of the Ascomycetes, that in their case there appear to be two complete nuclear fusions, one in the ascogonium and one, later on, in the ascus. Claussen, in his 
observations on Pyronema, considers that the fusion in the ascus should be regarded as the completion of the sexual fusion, for he maintains that, although there is a normal cell fusion of antheridium and ascogonium, there is no nuclear fusion in the ascogonium. He suggests that the male and female nuclei simply become paired in the ascogonium and subsequently divide by conjugate division in the ascogenous hyphae and fuse ultimately in the ascus. This would bring the Ascomycetes into line with Polyphagus and the Uredineae, but the very definite observations of Harper, followed by Blackman, Frazer, and others, that in some forms there is a nuclear fusion in the ascogonium as well as a subsequent fusion in the ascus, preclude our acceptance of the easy solution of the problem offered by Claussen, and we must look for it in another direction.

If we consider that in the nuclei of the Ascomycetes, as in other forms, we have the two elements, the generative and the vegetative, is it not possible to conceive the first fusion of the nuclei in the ascogonium as a purely vegetative fusion, and the second fusion in the ascus as the generative fusion? In other words, may not the nuclear fusion in the sexual apparatus and the nuclear fusion in the ascus be simply regarded as the vegetative and generative phases of a single sexual act which have become separated owing to the interpolation of a series of vegetative divisions between the formation of the ascogonium and the production of the ascospores?

This conjecture seems the more reasonable when we remember that in so pronounced a sexuality as that of Polyphagus the nuclei do not fuse in the zygote, but only those portions of the chromatin extruded from them which are obviously bound up with vegetative development. And it is further supported by the trend in the direction of non-sexual fusion shown by the Ascomycetes in general, as indicated by the total disappearance of cell fusion in many forms and its reduction to mere pairing in others, but leaving in all cases the generative fusion of nuclei in the ascus.

\section{SUMMARY.}

I. Polyphagus Euglenae is one of the few Chytridiaceae in which there is pronounced sexuality. Reproduction takes place by the production of zoospores in sporangia, which may be formed on the ordinary vegetative cells, or on cysts, or on the sexually produced zygotes.

2. The organism is parasitic on Euglena viridis. The thallus is unicellular and uninucleate, and is provided with delicate pseudopodia which penetrate the cells of the Euglenae and bring about complete disintegration of their contents. A single thallus may be in contact with as many as fifty Euglenae.

3. The zoospore possesses a single flagellum, at the base of which is a yellow oil-drop in close contact with the nucleus. The nucleus is 
surrounded by a deeply stained chromidial mass, which extends also around the oil-drop to the point of attachment of the flagellum. It is suggested that the yellow-coloured oil-drop may be functional in connexion with the phototaxis of the zoospores.

4. The nucleus of the vegetative cell contains a large chromatin nucleolus, which is frequently arc-shaped and is in close contact with a lightly stainable nucleoplasm. The nucleus is surrounded on all sides by a deeply stained mass of chromidia.

5. The zygotes are formed by the fusion of uninucleate gametes, which are equivalent to vegetative cells. They are placed in contact with each other by means of a copulating tube which is put out from the smaller or male cell and comes into contact with the larger, female cell. The apex of the copulating tube swells up and becomes the zygote. The contents of the male tube first pass into it, then the contents of the female cell.

6. The two sexual nuclei in the young zygote are at first unequal in size, but the smaller male nucleus grows, probably at the expense of nourishment brought in from the female cell, until it becomes equal in size to the female nucleus. Large quantities of chromatin are then extruded from the two nuclei to form two masses of chromidia which fuse and form a large granular mass for which the term 'chromidiosphere' (or 'chromidiocentrum ') is suggested. The significance of the chromidia and the chromidial fusion is briefly discussed.

7. The germination of the zygote has been followed in detail both in living and stained specimens. It was observed to take place in November, five months after the formation of the zygotes. The outer spiny coat is ruptured, and a delicate protuberance appears which develops into a zoosporangium similar to the ordinary asexual sporangium, except that it is usually much smaller. The two sexual nuclei do not fuse until after their entry into the sporangium.

8. Nuclear division takes place only in the sporangia, never in the vegetative cells, cysts, or zygotes. The process has been followed in the asexual sporangia. The spindle is internal; the nuclear wall breaks down first at the poles, where kinoplasmic substance with radiating striae appear. The prophases and anaphases of division appear to be those of normal mitosis, but, compared with the large amount of chromatin in the resting nucleus, the chromosomes are small.

9. With the exception of Olpidiopsis and Olpidium, the cytology of the Chytridiaceae is not very completely known, and there are many accounts of curious abnormal nuclear phenomena, especially in Synchytrium, which require elucidation in view of the perfectly normal mitosis in Polyphagus and Olpidiopsis.

10. Polyphagus shows relationships with various other genera of the Chytridiaceae, leading on the one hand to the Oomycetes and on the other 
to the Mucoriaceae. In its general structure and in the formation of chromidia it also shows some connexion with the Protozoa.

I I. In Polyphagus we can clearly see the dual nature of the nucleus in that the larger part of the chromatin contained in it is definitely extruded for purposes of metabolism, only a small part being left for nuclear division and reproduction.

I 2. The double fusion in Polyphagus, consisting of a chromidial fusion in the zygote followed by nuclear fusion in the sporangium, may afford some clue to the explanation of the delayed nuclear fusions and double nuclear fusions observed in the higher Fungi. This is briefly discussed.

\section{List OF PAPERS.}

Atkinson, G. F. : Some Problems in the Evolution of the Lower Fungi. Annales Mycologici, vol. vii, 5909 .

BaIL, TH.: Mycologische Berichte. III : Chytridium Euglenae. Bot. Zeit., vol. xiii, I855, p. 678 .

Bally, W. : Cytologische Studien an Chytridineen. Jahrb. f. wiss. Botanik, vol. 1, I9I r.

Barrett, J. T. : Development and Sexuality of some Species of Olpidiopsis, (Cornu) Fischer. Ann. Bot., vol. xxvi, I9I 2.

DE Bary, A. : Comp. Morph. and Biology of the Fungi, \&c. Eng. Edit., 1887, p. 162.

Berthold, G. : Studien über Protoplasmamechanik. Leipzig, 1886.

Bотт, K. : Ueber die Fortpflanzung von Pelomyxa palustris. Archiv f. Protistenkunde, vol. viii, 1907.

Braun, A. : Ueber Chytridium. Monatsberichte der Berliner Akademie, I 855.

: Ueber Chytridium, eine Gattung einzelliger Schmarotzergewächse. Abhandlungen der Berliner Akad., 1856.

Rhizidium. Monatsb. d. Berl. Akad., 1856.
Mand

Büsgen, M.: Die Entwicklung der Phycomycetensporangien. Pringsheim's Jahrb. f. wiss. Botanik, vol. xiii, I 882 .

Dangeard, P. A.: Recherches sur la structure du Polyphagus Euglenae, Nowak. Le Botaniste, vol. vii, 1900.

: Recherches bistologiques sur les Champignons, Le Botaniste, vol. ii, I 890.

: Structure et communications protoplasmiques dans le Bactridium favum. Le Botaniste, vol. vii, 1900.

Goldschmidt, R. : Die Chromidien der Protozoen. Archiv f. Protistenkunde, vol, v, 1904.

Griggs, R. F. : Mitosis in Synchytrium. Bot. Gazette, vol. xlviii, 1909.

: Some Aspects of Amitosis in Synchytrium. Bot. Gaz., vol. xlvii, I909.

: Monochytrium: a New Genus of the Chytridiales, its Life History and Cytology. Ohio Nat., vol. $x$, Igio.

Gros, G. : De l'embryogénie ascendante des espèces on génération primitive, équivoque et spontanée et métamorphoses de certains animaux et végétaux inférieurs. Bull. de la Soc. Imp. des Sciences Nat. de Moscou, 185 I.

Harper, R. A. : Cell Division in Sporangia and Asci. Ann. Bot., vol. xiii, 1899.

: Sexual Reproduction in Pyronema confluens, \&c. Ann. Bot., vol, xiv, 1900. 
HARTOG, M.: On the Formation and Liberation of the Zoospores of the Saprolegniae. Q. J. M. S., N. S., I 887 .

: Recent Researches on the Saprolegniae; a Critical Abstract of Rothert's Results. Ann. Bot., vol. ii, $\mathbf{1} 888$.

: On the Cytology of the Vegetative and Reproductive Organs of the Saprolegniae. Trans. R. Irish Academy, vol. xxx, 1895 .

Hertwig, R.: Die Protozoen und.die Zelltheorie. Archiv f. Protistenkunde, vol. i, i $90 \%$.

Kusano, S. : On the Cytology of Synchytrium. Centralbl. f. Bakt. \&c., 2. Abt., vol. xix, igog.

KWAKINe, W.: Recherches biologiques sur l'Astasia ocellata n.s. et l'Euglena viridis, Ehr. Ann. d. Sci. Nat., Zool., 7th series, vol. i, i 886.

Loewenthal, W. : Weitere Untersuchungen an Chytridiaceen. Archiv f. Protistenkunde, vol. v, I905.

Mesnil, F.: Chromidies et questions connexes. Bull. de l'Institut Pasteur, vol. iii, I905.

Mrnchin, E. A. : An Introduction to the Study of the Protozoa. London, I9 I 2.

Nowakowski, L. : Beitrag zur Kenntniss der Chytridiaceen. II : Polyphagus Euglenae, eine Chytridiacee mit geschlechtlicher Fortpflanzung. Cohn's Beitr. z. Biol. d. Pflanzen, vol. ii, $1876-77$.

: Ueber Polyphagus (in Polish). Abh. d. Krakaner Akad., 1878.

Pavillard, J. : État actuel de la protistologie végétale. Progressus rei Botanicae, vol. iii, igio.

Percival, J.: Potato 'Wart' Disease; the Life History and Cytology of Synchytrium endobioticum (Schilb.). Centralbl. f. Bakt., \&c., vol. xxv, I909.

Prowazek, S. v.: Die Erreger der Kohlhernie, Plasmidiophora brassicae. Arbeiten aus dem kaiserlichen Gesundheitsamte (Berlin), vol. xxii, I905.

Rosen, F.: Studien über die Kerne und die Membranbildung bei Myxomyceten und Pilzen. Cohn's Beiträge zur Biologie der Pflanzen, vol. vi, I892-3, p. 237.

Rothert, W. : 'Rozwój Zarodni u Grzbów z. Rodziny Saprolegnieae' (Formation of Sporangia and Spores in the Saprolegnieae). Proceedings of the Cracow Acad., vol. xvii, I887. See also Cohn's Beiträge, I 888 .

Schaudinn, F. : Die Fortpflanzung einiger Rhizopcden. Arbeiten aus dem kaiserlichen Gesundheitsamte, vol. xix, I903.

Schenk, A.: Algologische Mittheilungen. Verhandlungen der phys.-med. Gesellschaft zu Würzburg, viii, I 857 .

Schroeter, J.: Chytridineae, in Engler und Prantl, 'Die natürlichen Pflanzenfamilien.' Teil I, Abt. I, I 889-97 (Parts 76, I 892, and 93, I 893).

Siebold, C. Th. von, and Meissner : (Ref. in Nowakowski, 1876-7, p. 201 ), i 855.

Stevens, F. L.: Some Remarkable Nuclear Structures in Synchytrium. Annales Mycologici, vol. v, 1907.

Stevens, F. L. and A. C.: Mitosis in the Primary Nucleus in Synchytrium decipiens. Bot. Gaz., vol. $\mathrm{xxxv}, \mathrm{I} 9 \mathrm{O}^{3}$.

WAger, Harold: The Formation of the Zygospore in Polyphagus Euglenae. Report of the Brit. Ass., Bristol, 1898, p. 1064 .

: The Sexuality of the Fungi. Ann. Bot., vol. xiii, r899.

: On some Problems of Cell Structure and Physiology. Presidential Address to the Botanical Section, Brit. Ass. Report, S. Africa, 1905.

1896. xxvii, 1899 .

Ward, H. MARShall: Observations on Saprolegniae. Q. J. M.S., N.S., vol. xxiii, i88z.

Zuelzer, M. : Diffugia urceolata. Archiv f. Protistenkunde, vol. iv, 1904. 


\title{
DESCRIPTION OF FIGURES IN PLATES XVI-XIX.
}

\author{
Illustrating Mr. Harold Wager's paper on Polyphagus.
}

(Except where otherwise stated the figures have been drawn with the aid of a camera lucida, using the apoc. obj. $2 \mathrm{~mm}$. of Zeiss and compensating oc. 8.)

\section{PLATE XVI.}

Fig. ז. Copulation of male and female cells. Copulating tube very long. The young zygote is just beginning to form as a swelling at the apex of the copulating tube in contact with the female cell. (Obj. Zeiss D, oc. 8, Cam. lucida sketch.)

Fig. 2. Male nucleus just ready to pass along the copulating tube into the young zygote. The copulating tule shows three slight swellings along it.

Fig. 3. Zygote at a slightly later stage than in Fig. I. Copulating tube larger in diameter and shorter. (Obj. Zeiss D, oc. 8, Cam. luc. sketch.)

Fig. 4. Young zygote, showing male and female nuclei just about to pass into it. Copulating tube short. (Obj. $2 \mathrm{~mm}$. apoc., oc. 8, freehand sketch.);

Fig. 5. Young zygote, showing male nucleus inside and female nucleus ready to pass in. (Obj. Zeiss D, oc. 8, freehand sketch.)

Figs. 6-2 I. Germination of zygote. (Obj. Zeiss D, oc. 4, freehand sketches.)

Fig. 6. Zygote just beginning to germinate in November.

Fig. 7. Shows contents of zygote with fatty granules.

Fig. 8. Ditto, later stage.

Fig. 9. Oily masses beginning to break up.

Fig. 1o. Oily masses breaking up into minute granules which appear black under microscope.

Fig. I I. Vacuoles appear; further breaking up of fat granules.

Fig. I 2. Fat completely broken up into minute granules arranged in strings.

Fig. I3. Minute fat granules surrounding vacuoles.

Fig. I4. Ditto, more regular arrangement of vacuoles.

Fig. I5. Fat globules fusing together.

Fig. 16. Later stage of fusion.

Fig. I7. Granules, much fewer, nearly all same size, one for each zoospore.

Fig. I 8 . Contents divided into polygonal masses, the young spores.

Fig. I9. The spores completely separated.

Fig. 20. The spores, just before they escape, become slightly elongated.

Fig. $2 \mathrm{x}$. Spores escaping; the three shown were unable to get out for some time.

Figs. 22-25. Successive stages in the segregation of spores in a portion of an asexual sporangium. (Obj. Zeiss D, oc. 4, freehand sketches.)

\section{PLATE XVII.}

Fig. 26. Sporangium just beginning to form on the vegetative cell.

Fig. 27. Young sporangium just formed on the vegetative cell with nucleus just passing into it, surrounded by a deeply stainable chromidial mass with oil globules. The large nucleolar mass of chromatin has become constricted, in its passage through the opening, into a large anterior and a small posterior portion, with a drawing-out thread between them.

Fig. 28. Sporangium just being formed. The membrane around it is visible and is seen to be continuous with that of the male cell. The nucleus has just passed into the sporangium, and in the passage a small portion of it has been left behind. A number of chromidial granules are scattered in the protoplasm which is passing into the sporangium. The rest of the chromatin mass (nucleolus) 
has become arc-shaped, and appears of a peculiar spongy texture. The nucleoplasm is in contact with it.

Fig. 29. Young sporangium with two nuclei, each with a sickle-shaped mass of chromatin and a smaller granule or group of minute granules.

Fig. 30. Young sporangium with two nuclei in process of division. Near each nucleus is a quantity of chromatin, probably extruded from the nuclei for purposes of metabolism. This is probably derived from the large sickle-shaped chromatin mass or nucleolus which is found in the resting stage.

Fig. 3I. Sporangia with four nuclei, three of which are shown. They appear to have just finished dividing. A few fine fibrils are seen extending between the pair of nuclei shown, and the groups of chromosomes in the newly constituted danghter nuclei are visible. There are two deeply stained chromatin masses in the cytoplasm.

Fig. 32. Sporangium with four nuclei, each with peripheral chromatin mass and nucleoplasm.

Fig. 33. Sporangium with four nuclei, all in process of division. Equatorial plate just forming. The lateral walls of each nucleus prominent and deeply stained. At the poles of the nuclei are wellmarked radiating striae.

Fig. 34. Upper two-thirds of a sporangium with four nuclei, all of which are shown in the part drawn. Two large, deeply stained granules and two smaller ones, probably extruded from the nuclei during division.

Fig. 35. Sporangium showing the reconstruction of the daughter nuclei. A few delicate strands, the remnants of the spindle, are still visible, extending between the young nuclei, and near these are large stained granules, probably the remains of the nucleoli.

Fig. $3^{6}$. Sporangium with eight nuclei. The nucleolar body forms a sickle-shaped mass at the periphery of each nucleus.

Fig. 37. Portion of sporangium with 32 nuclei. A deeply stained arc of substance is applied against the nuclear membrane of each. The granular or thread-like substance in the centre is probably just about to break up into chromosomes.

Fig. 38. One half of a sporangium with 32 nuclei, all in process of division. The spindle is clearly shown, and at the poles of some of the nuclei kinoplasmic masses (centrosomes?) with radiating striae are to be seen. The nuclear membrane is thickened laterally. One of the nuclei shows clearly ten chromosomes.

Fig. 39. Sporangium with 32 nuclei, all dividing. Apparently a later stage than Fig. 38 . The nuclei are flattened slightly at the poles, where the kinoplasm is prominent with radiating striae. No granules which could be distinctly called centrosomes were visible in the kinoplasmic masses, although these sometimes appeared to be granular.

Fig. 40. Young sporangium with eight nuclei, all in division stage, showing equatorial plate, spindle, and appearance of radiating striae at the poles of the nuclei. The spindle seems to be formed out of the lightly stained fine network in the nucleus, and appears before the wall breaks down at the poles.

Fig. 4I. Portion of sporangium containing about 32 nuclei in state of division. The drawing shows an optical section of a portion with eight nuclei. Four of the nuclei, being at a different level, are not shown. Between the groups of daughter chromosomes in each case is an oval or spherical mass slightly less deeply stained than the chromosomes, probably the remains of the nucleolus.

\section{PLATE XVIII.}

Fig. 42. Portion of a sporangium in which there were probably 64 nuclei, all in a late stage of division. The spindle fibres connecting the groups of daughter chromosomes are visible, and near each is a deeply stained granule, probably extruded from the nucleus during division.

Fig. 43. Portion of sporangium with 16 nuclei just divided. Eleven of these are shown in the drawing. Between the pairs of nuclei delicate fibres are still visible, and the cytoplasm contains some deeply stained granules.

Fig. 44. Portion of sporangium just before the segregation of the zoospores. There were 32 nuclei present, $\mathbf{I} 6$ of which are shown. 
Fig. 45. Portion of sporangium in which there were 64 spores just separated, 16 of which are shown in the drawing. Each spore contains a well-marked nucleus and granular cytoplasm.

Fig. 46. Part of sporangium showing segregation of spores. Each spore-origin contains a nucleus and oil-drop, around which are to be seen deeply stained chromidial masses. The delicate lines of demarcation between the zoospores are visible.

Fig. 47. Portion of sporangium showing fully formed spores.

Fig. 48. Zoospore, showing oil-drop at base of cilium and near it the nucleus; both oil-drop and nucleus are surrounded on all sides by the deeply stained chromidial mass. (Obj. 2 mm., oc. 8, freehand sketch.)

Figs. 49-53. Five stages in the germination of a zoospore after it had come to rest. Fig. 49 was drawn at 9.30 a.m., Fig. 50 at I0.30 a.m., Fig. $5^{\text {I }}$ at II.40 a.m., and Fig. 53 at I2.25 p.m. (Obj. Zeiss D, oc. 4, freehand sketches.)

Fig. 54. Young vegetative cell, showing pseudopodia which appear to be continuous with the cell body and with the deeply stained chromidial mass surrounding the nucleus. (Obj. 2 mm., oc. 8 , freehand sketch.)

Fig. 55. Vegetative cell showing the granular chromidial network with included oil globules surrounding the nucleus.

Fig. 56. Freehand sketch, showing how the haustoria of Polyphagus penetrate the cell of Euglena and branch in all directions. The cell is full of paramylum grains. The preparation was made by staining alcoholic specimens in iodine solution.

Fig. 57. Young zygote. Male nucleus just passing into it; female nucleus ready to enter; copulating tube very short.

Fig. 58. Zygote and female cell. The male nucleus is already in the zygote. The large nucleus of female cell is surrounded by a deeply stained chromidial mass.

Fig. 59. Female nucleus just in the act of passing into the zygote. The nucleolus is elongate and constricted, showing how plastic it is.

Fig. 6o. The female nucleus has just arrived in the zygote, and is in close contact with the male nucleus, which is much the smaller of the two.

Fig. 6r. The zygote with the two sexual nuclei in close contact. The male nucleus gradually increases in size, probably at the expense of material brought in from the female cell. Deeply stained chromidia are scattered here and there in the cytoplasm.

Fig. 62. Sexual nuclei equal in size, and separated to opposite sides of the zygote.

Figs. 63-66. Four stages, showing the extrusion of chromidia from the zygote nuclei. The nuclei become smaller as the chromatin is extruded.

Fig. 67. Zygote showing the two small generative nuclei and the two chromidial masses.

\section{PLATE XIX.}

Fig. 68. The chromidial masses are fusing together.

Fig. 69. Fusion of the chromidia complete. This large central mass, which is so conspicuous in mature zygotes, may be distinguished as the chromidiocentrum or the chromidiosphere.

Fig. 70. Shows the two nuclei embedded in the chromidiosphere. The chromatin mass in each nucleus shows about ten granules (chromosomes?).

Fig. 7I. The two nuclei at the periphery of the chromidiosphere.

Fig. 72. The two nuclei slightly embedded in the chromidiosphere. fusion.

Fig. 73. Chromidiosphere irregular in shape, nuclei embedded in it. Stage probably just after

Fig. 74. The chromidia begin to lose their staining capacity just previous to germination.

Fig. 75. Germination of zygote ; the two sexual nuclei just about to pass into the sporangium.

Fig. 76. The two sexual nuclei just in the act of passing into the sporangium. One nucleus already in the sporangium, the other elongate and constricted, just passing through the narrow aperture.

Fig. 77. The two sexual nuclei in the young sporangium.

Fig. 78. Slightly later stage.

Fig. 79. Still later stage ; the nuclei are very close together, probably fusing. 

each.

Fig. 80. Similar stage to Fig. 79, but each nucleus shows granules estimated at about Io-I2

Fig. 8I. Two nuclei in the fusing stage, chromosomes clear. There appeared to be about ten in each nucleus, but this was not certain.

Fig. 82. Single nucleus of sporangium, due to fusion of the two sexual nuclei.

Fig. 83. Sporangium showing a nucleus in what seems to be a division stage.

Fig. 84. Division of primary nucleus of sporangium into two.

Fig. 85. Sporangium showing late stage of two dividing nuclei. The number of chromosomes in each daughter nucleus could not be counted, but appeared to be not greater than ten. 
Annals of Botany,

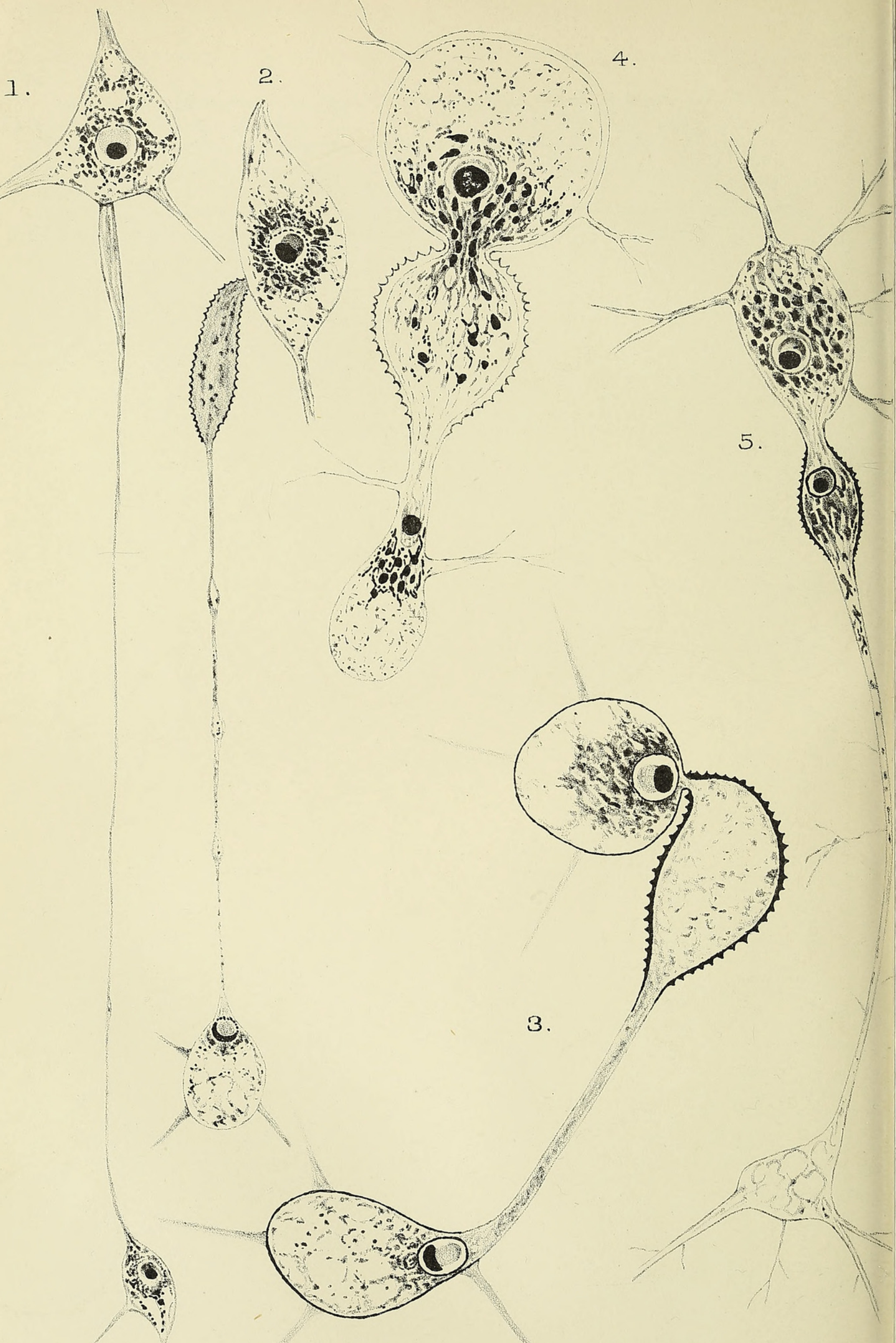

WAGER - POLYPHAGUS EUGLENAE. 
Vol.XXVII. PL.XVI.

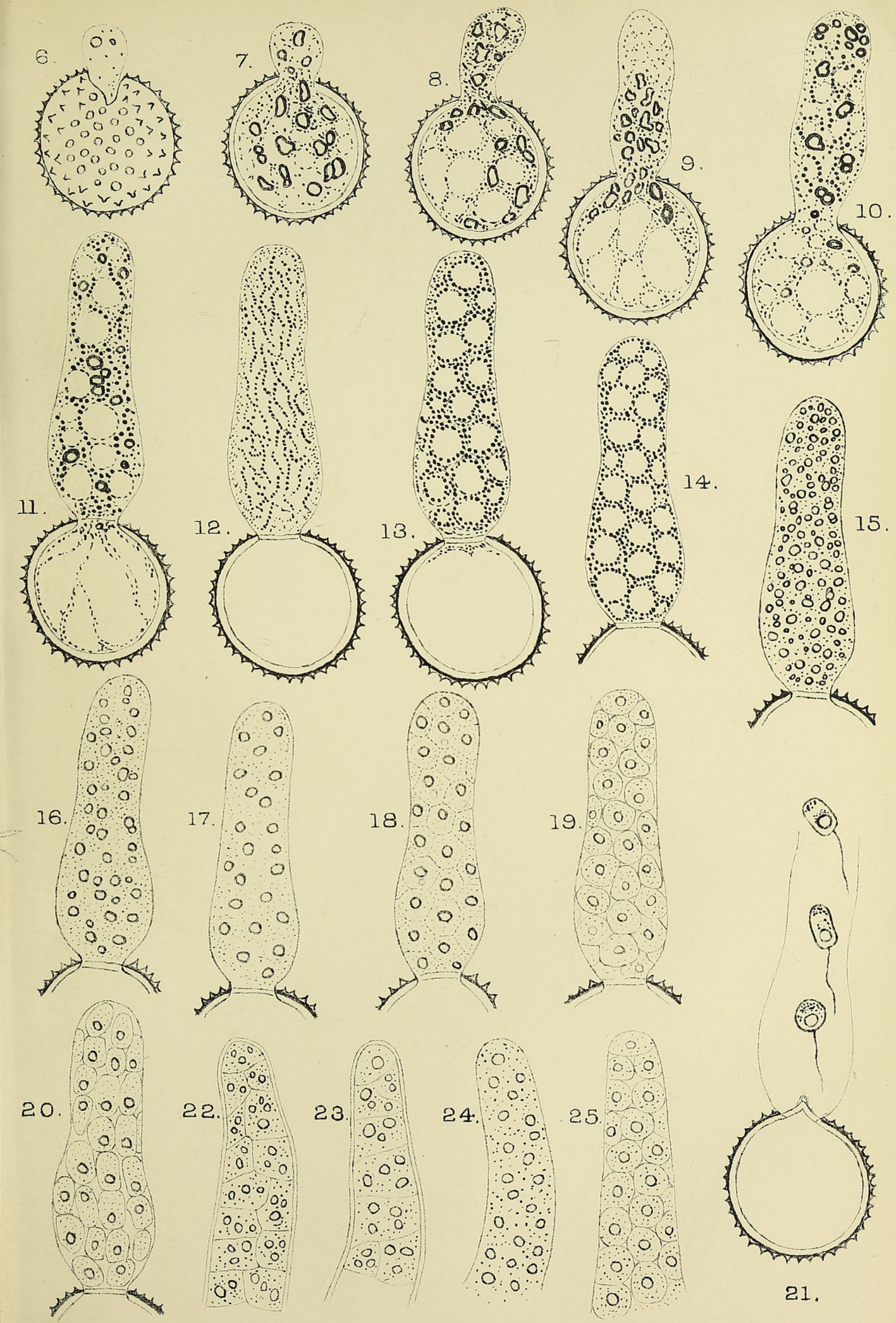

Huth lith et imp 


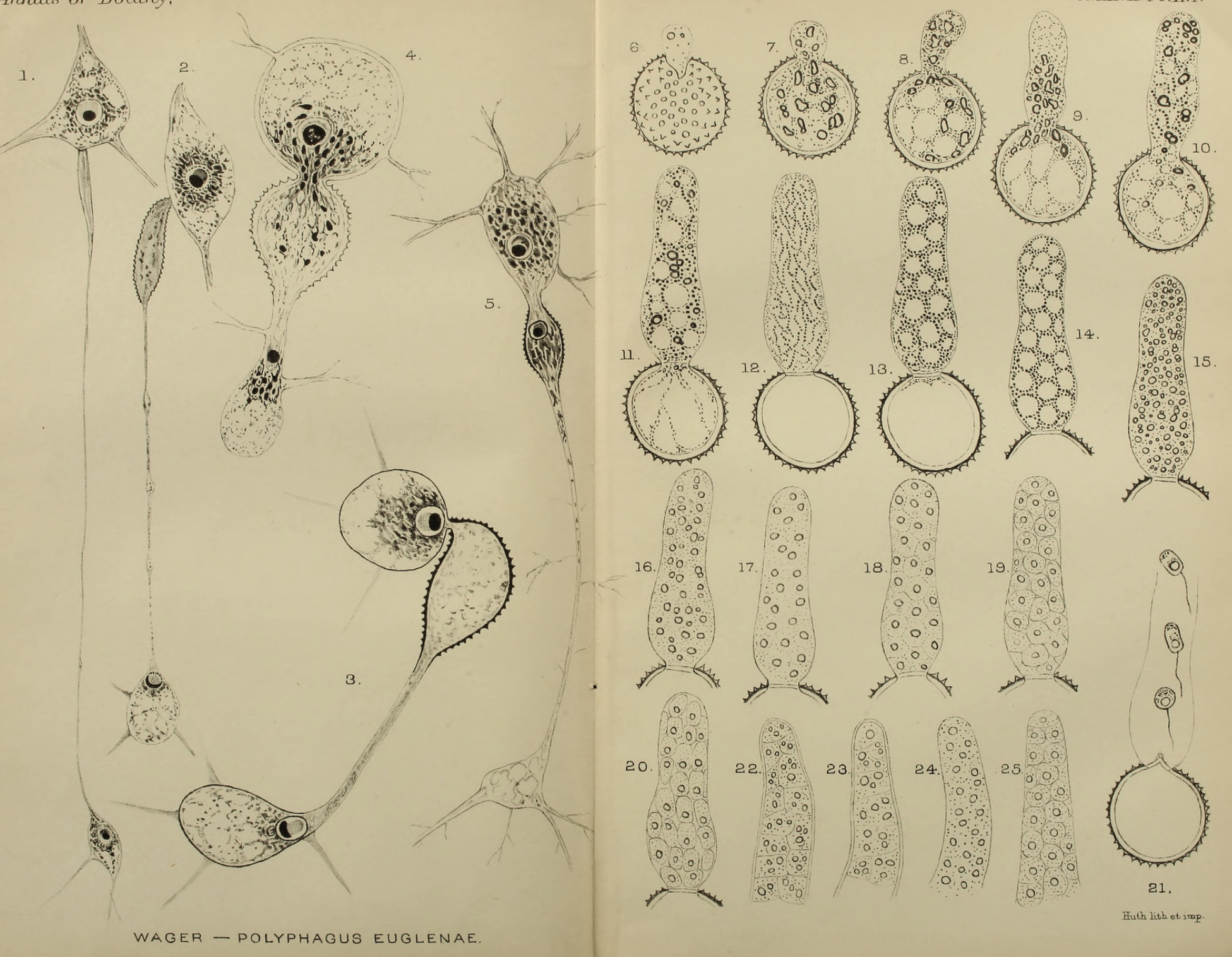


Annals of Botany.

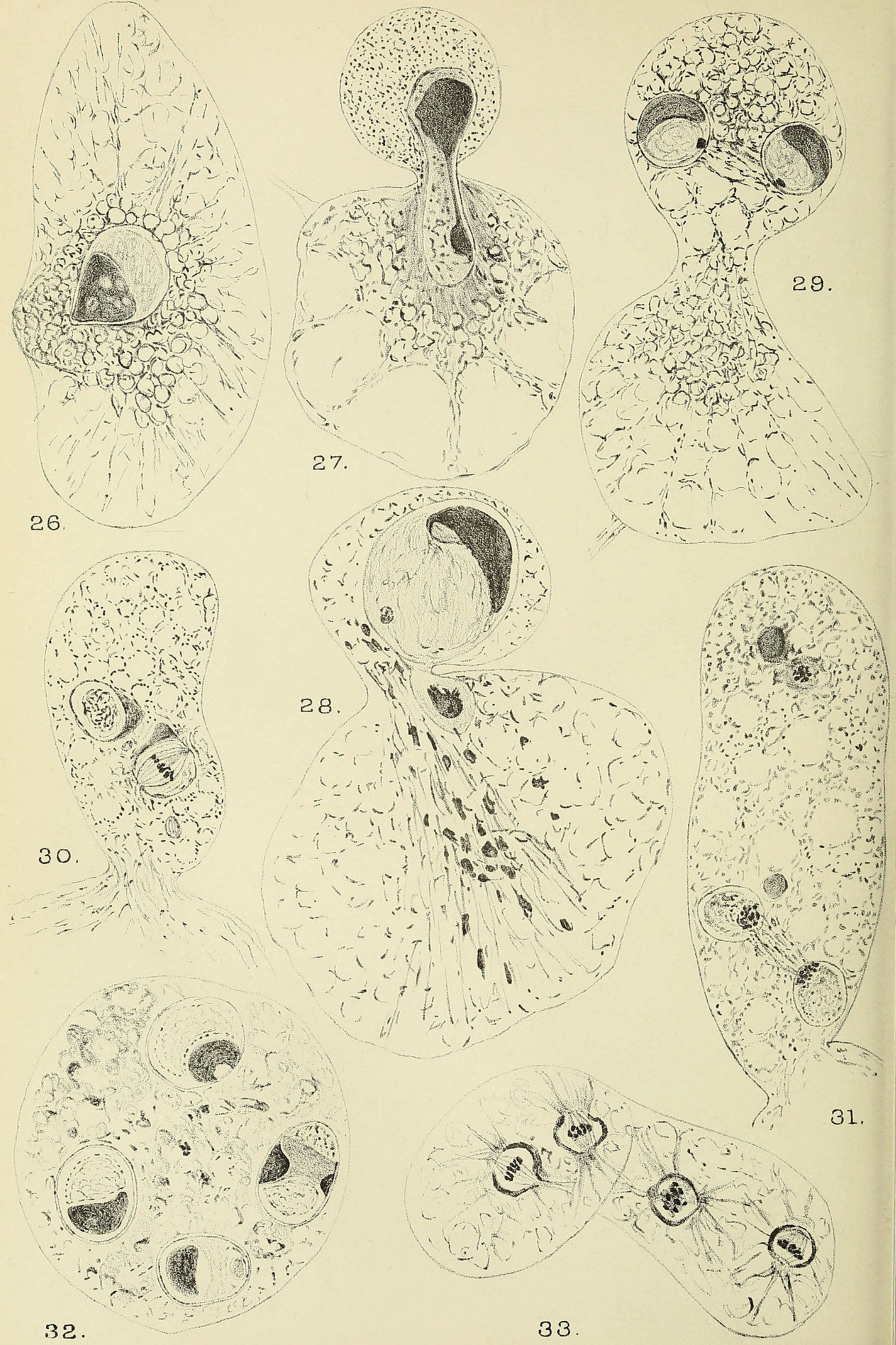



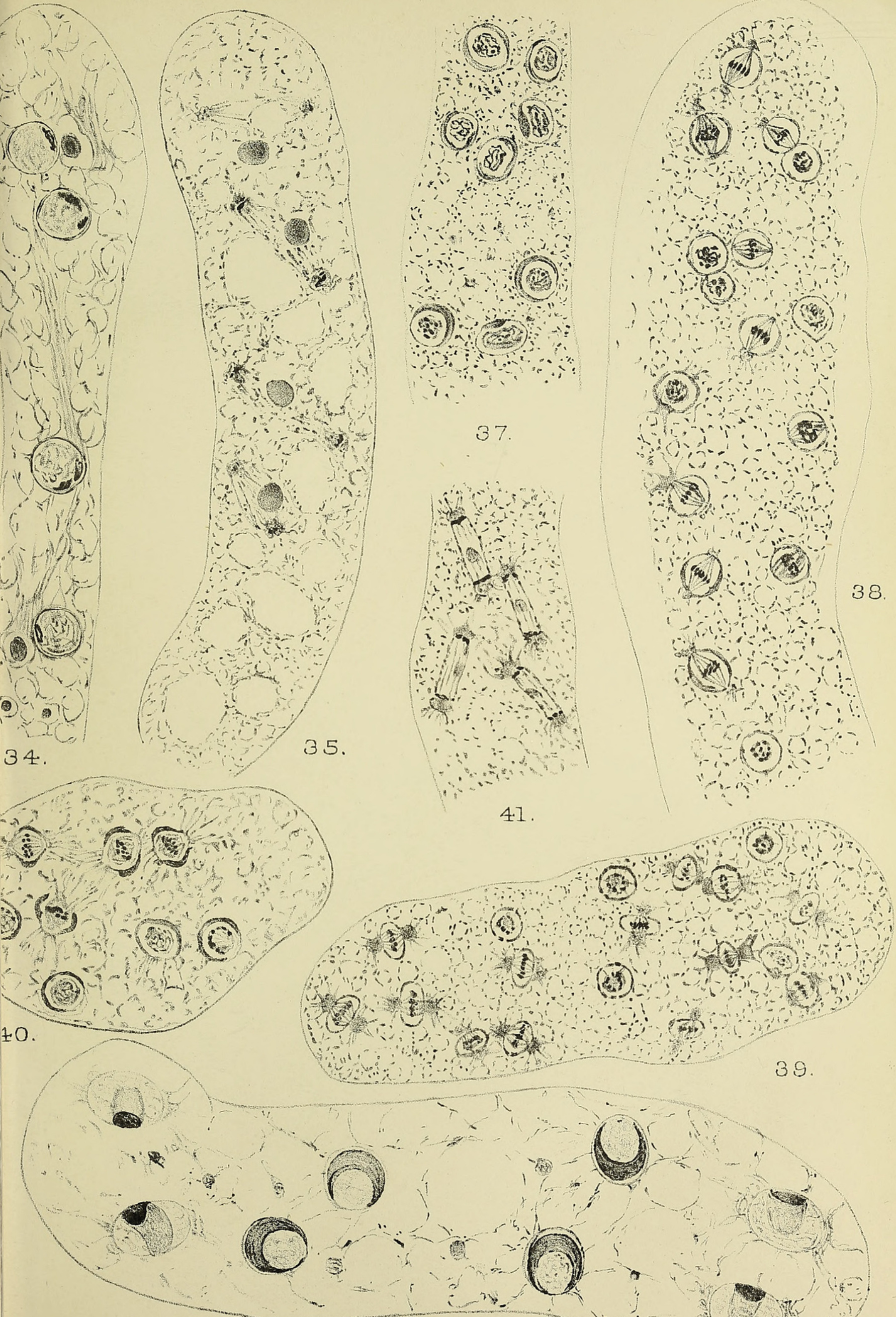

36. 
Annals of Botany.

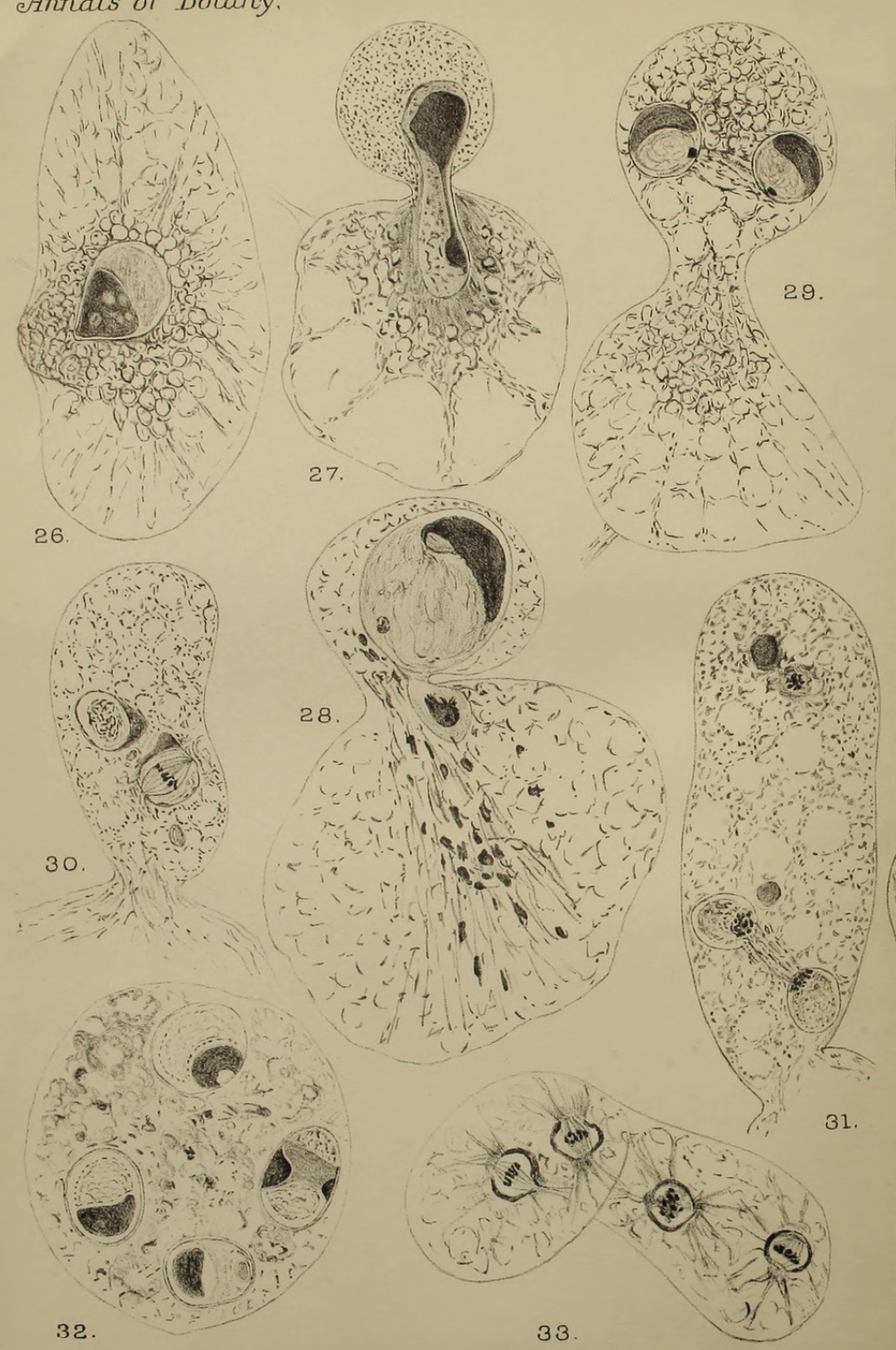

WAGER - POLYPHAGUS EUGLENAE
Vol.XXVII,PL.XVII.

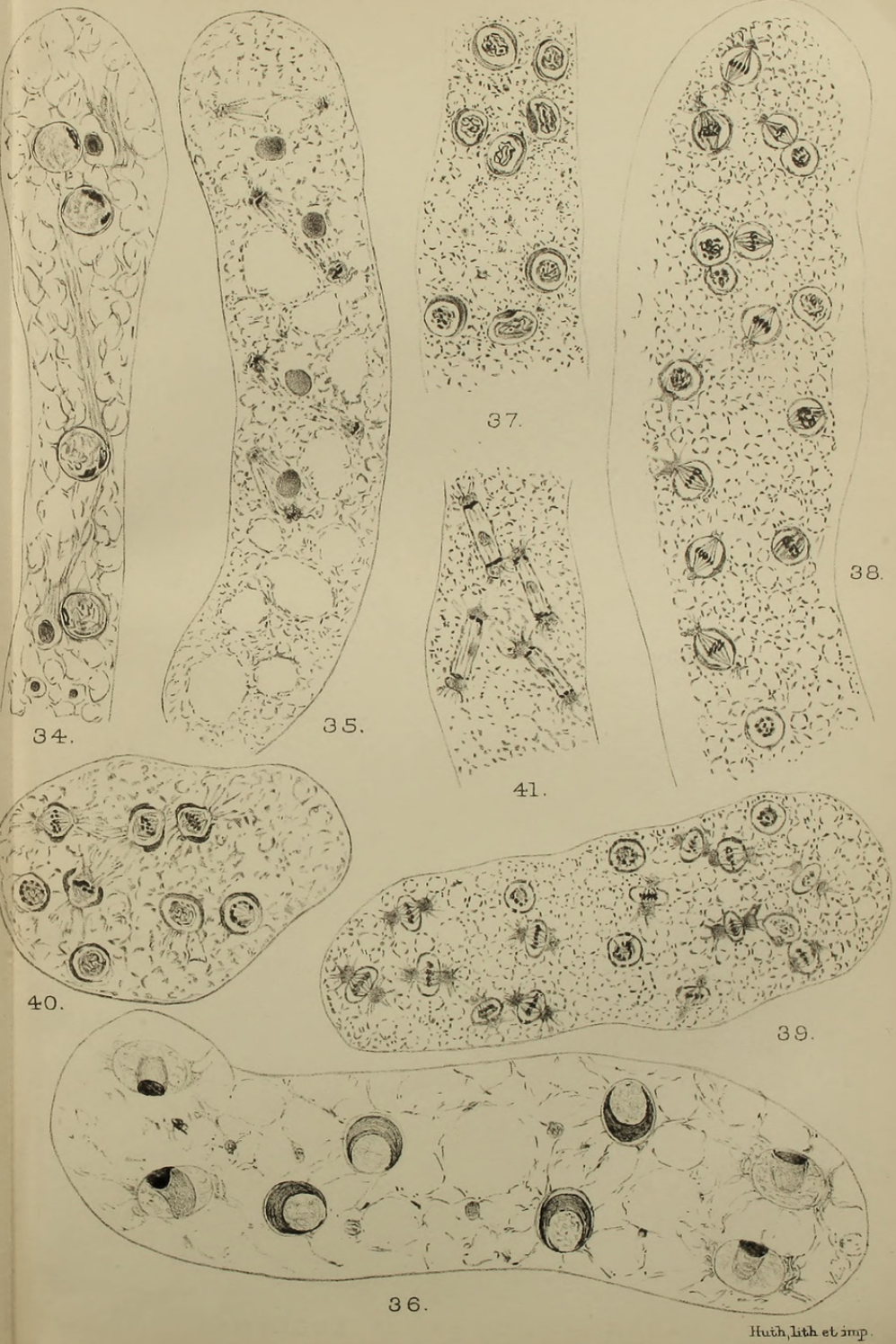


Annals of Botany,

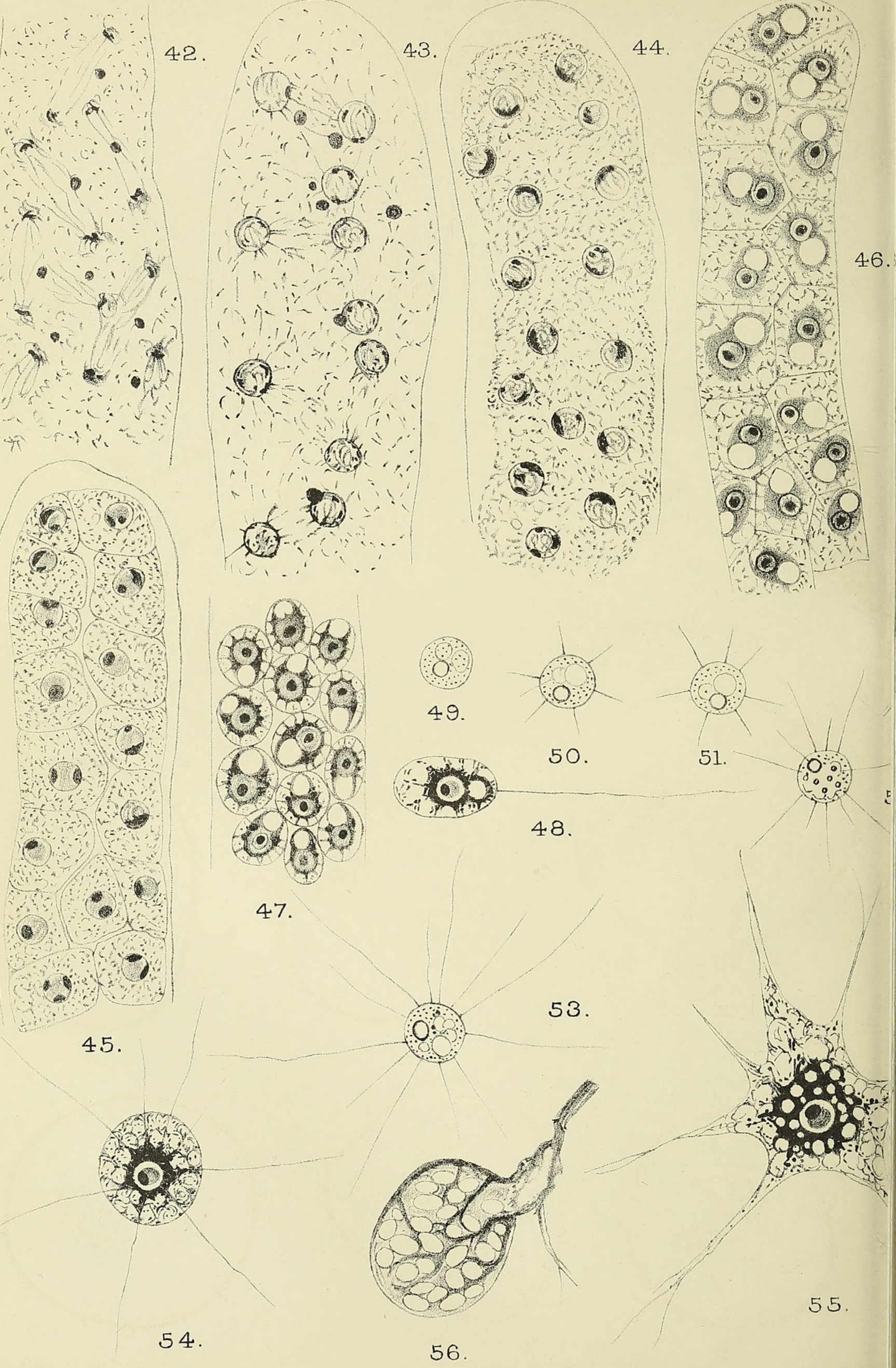


Vol. XXVII,PL. XVIII.

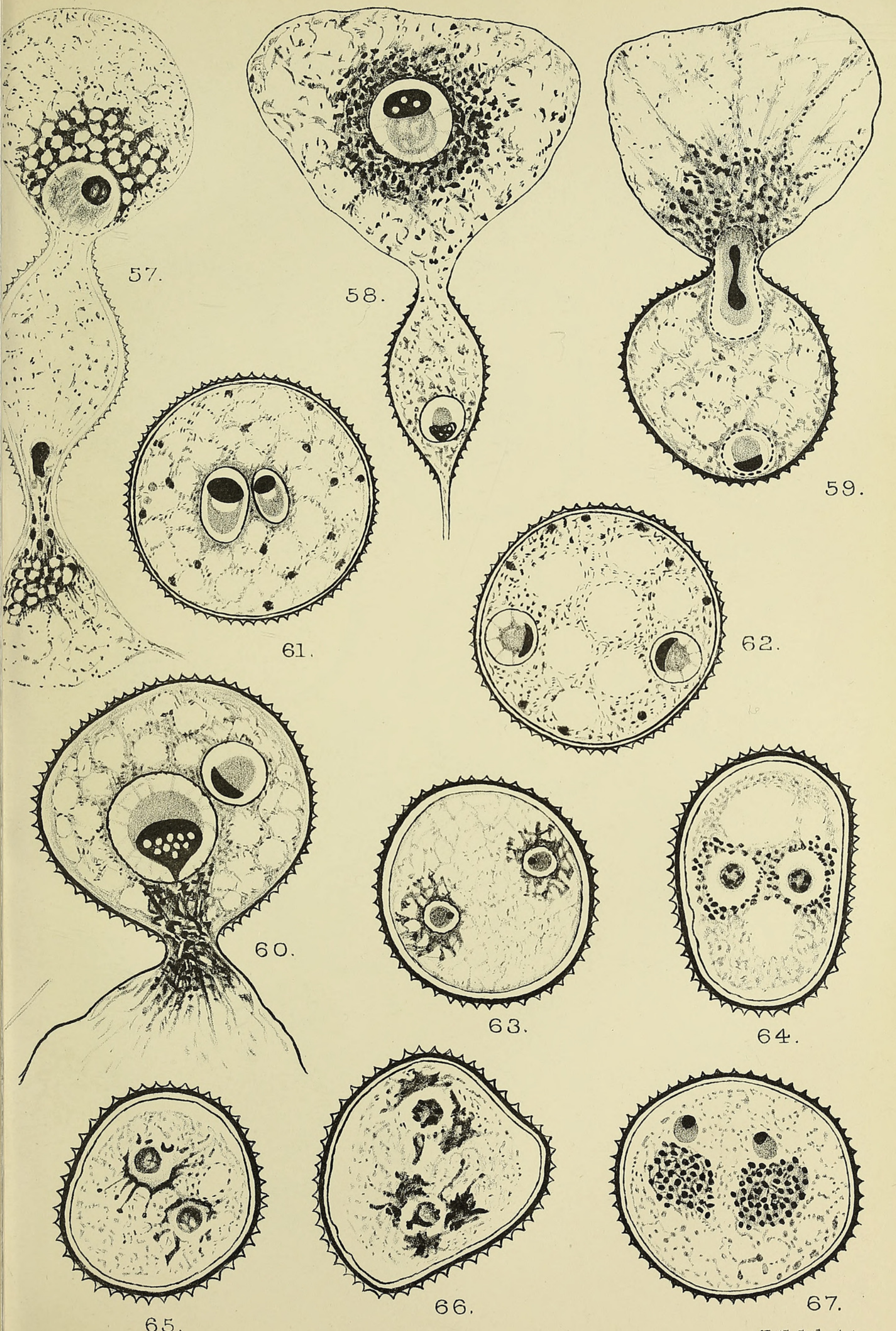

Huth, lith et.imp. 


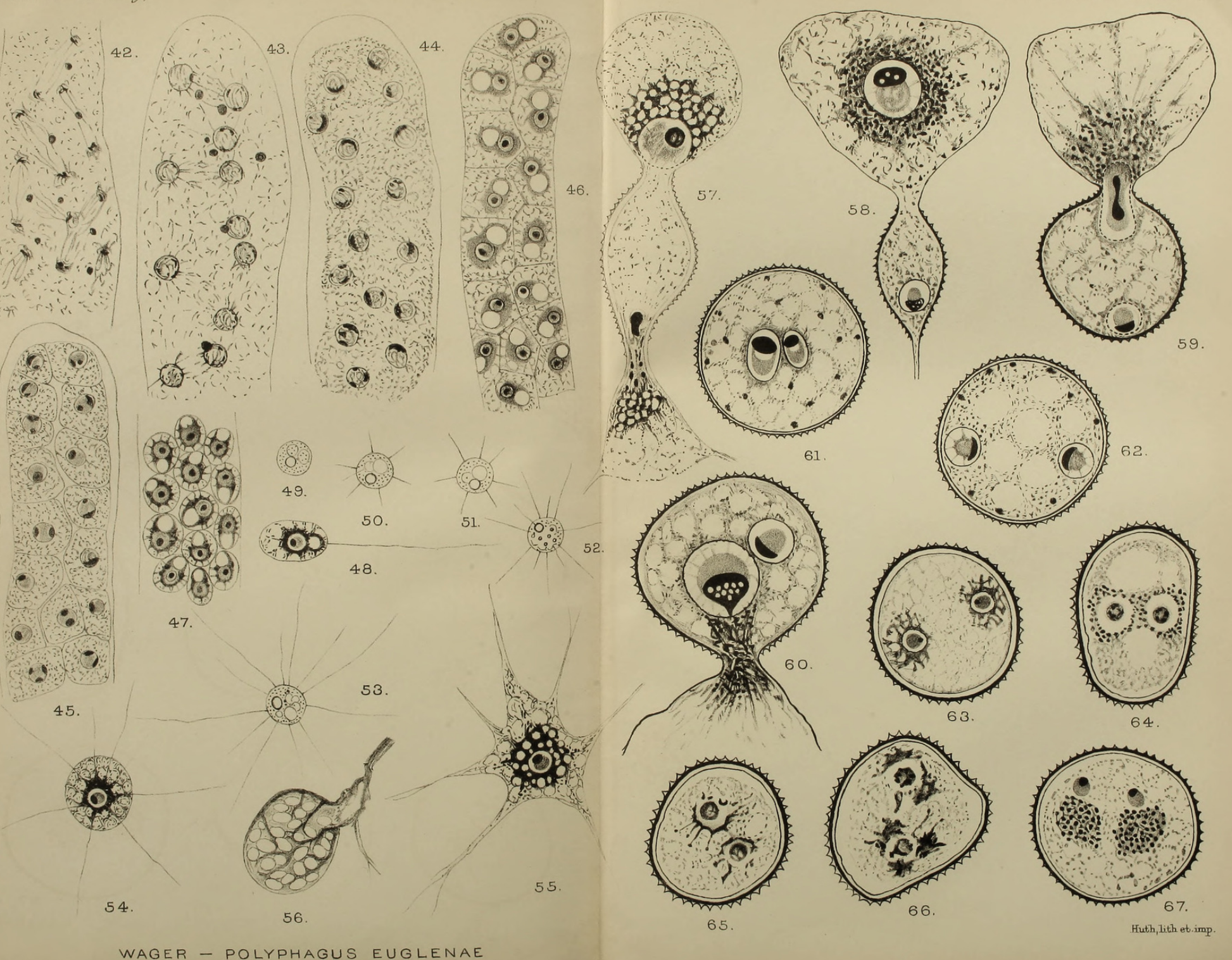


Annals of Botany,

Vol. XXVII, PI.XIX.
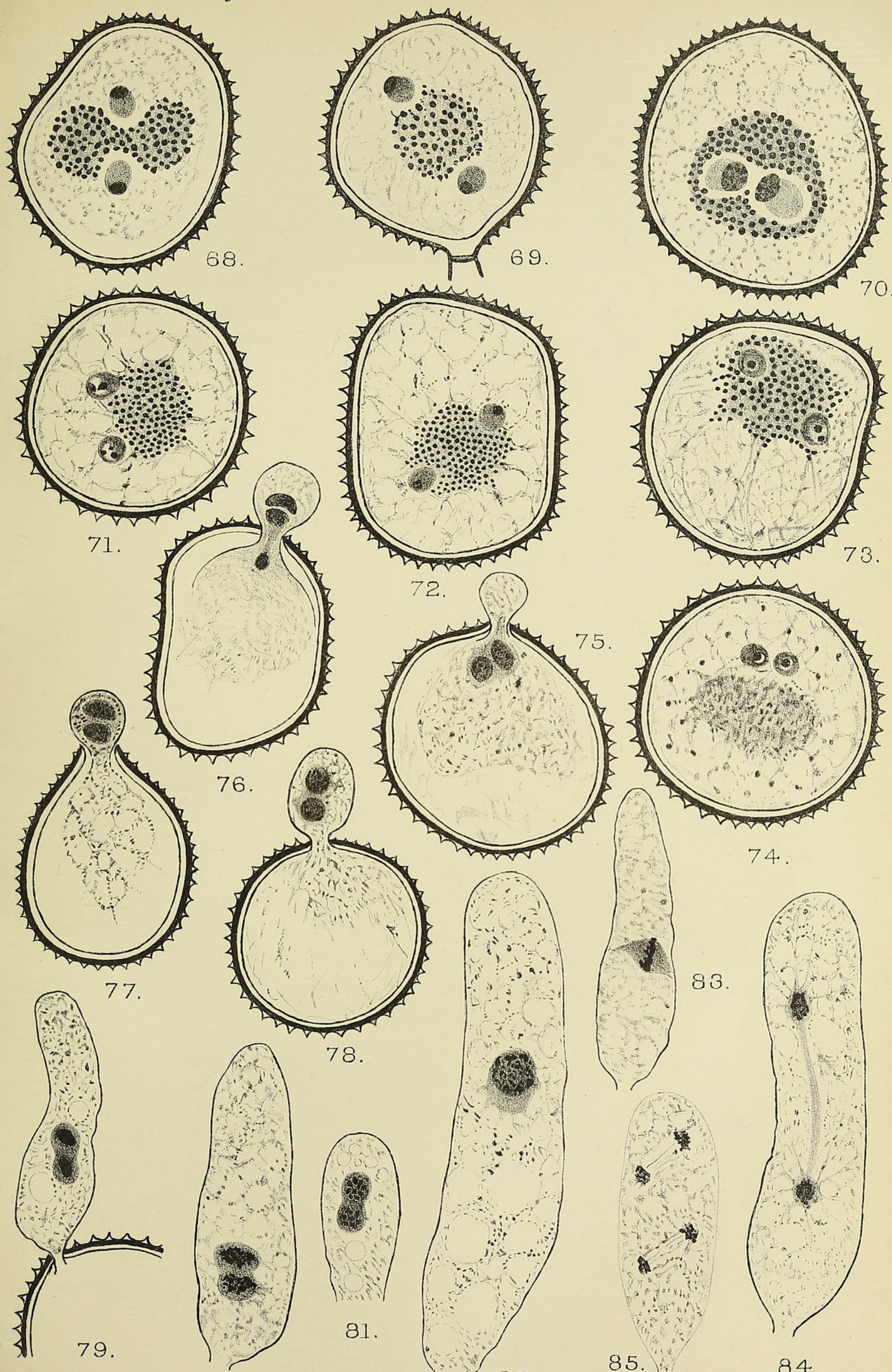

80
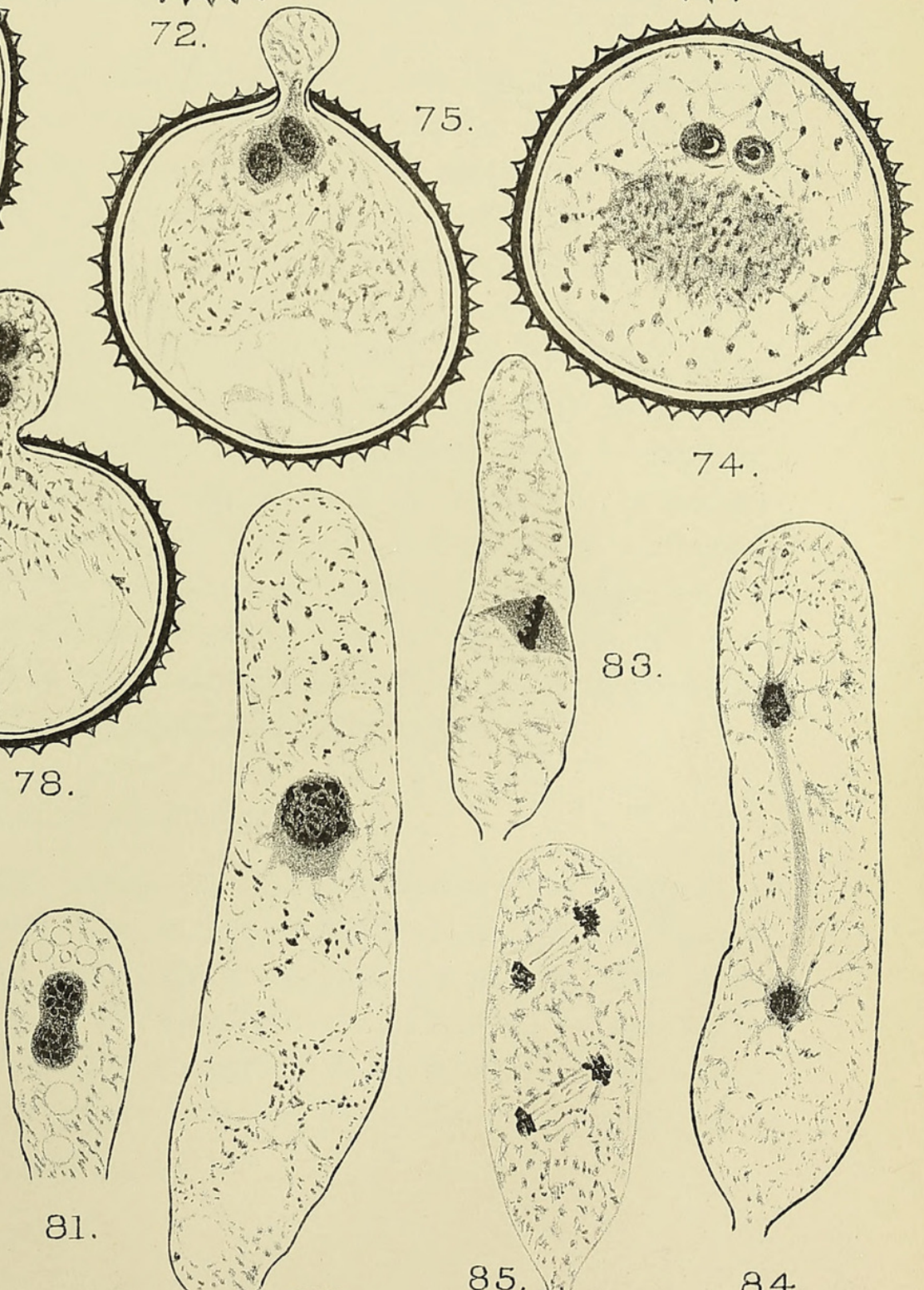

82

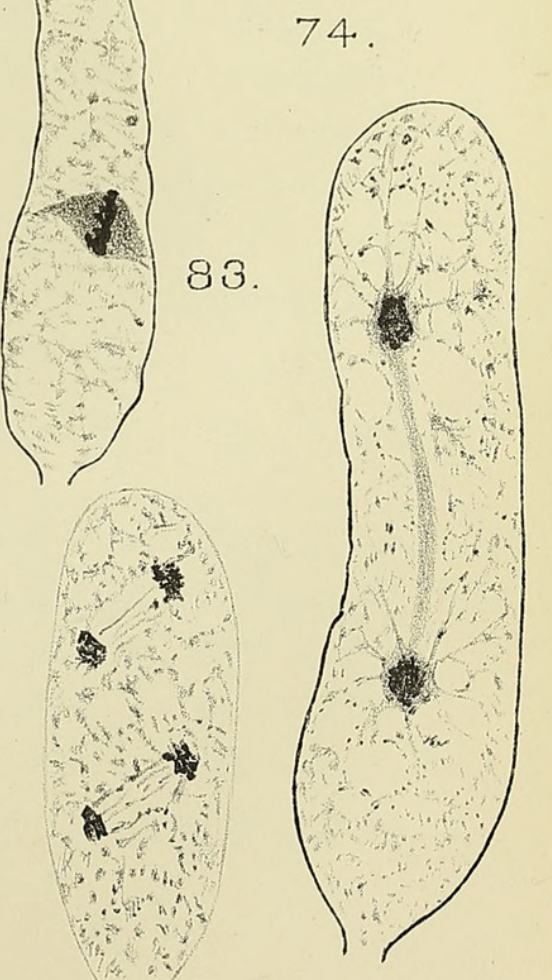

85.

84.

WAGER - POLYPHAGUS EUGLENAE 


\section{$2 \mathrm{BHL}$ Biodiversity Heritage Library}

Wager, Harold W. T. 1913. "The life-history and cytology of Polyphagus euglenae." Annals of botany 27, 173-202. https://doi.org/10.1093/oxfordjournals.aob.a089455.

View This Item Online: https://www.biodiversitylibrary.org/item/237410

DOI: https://doi.org/10.1093/oxfordjournals.aob.a089455

Permalink: https://www.biodiversitylibrary.org/partpdf/319968

\section{Holding Institution}

Smithsonian Libraries

\section{Sponsored by}

Biodiversity Heritage Library

\section{Copyright \& Reuse}

Copyright Status: Not in copyright. The BHL knows of no copyright restrictions on this item.

This document was created from content at the Biodiversity Heritage Library, the world's largest open access digital library for biodiversity literature and archives. Visit BHL at https://www.biodiversitylibrary.org. 